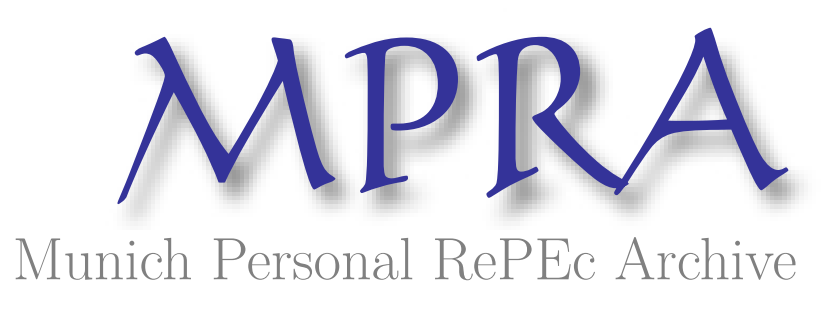

\title{
The Emergence of A Parallel World: The Misperception Problem for Bank Balance Sheet Risk and Lending Behavior
}

Inoue, Hitoshi and Nakashima, Kiyotaka and Takahashi, Koji

Sapporo Gakuin University, Konan University, Bank of Japan

26 July 2018

Online at https://mpra.ub.uni-muenchen.de/89088/

MPRA Paper No. 89088, posted 20 Sep 2018 03:46 UTC 


\title{
The Emergence of A Parallel World: The Misperception Prob- lem for Bank Balance Sheet Risk and Lending Behavior *
}

\author{
Hitoshi Inoue ${ }^{\dagger}$ \\ KIYOTAKA NAKASHIMA $\ddagger$ \\ SAPporo Gakuin University \\ KONAN UNIVERSITY
}

KOJI TAKAHASHI ${ }^{\S}$

BANK OF JAPAN

July, 2018

\begin{abstract}
We examine the reason that there have coexisted the two opposing views on distressed banks' lending behavior in Japan's post-bubble period: the one is the stagnant lending in a capital crunch and the other is the forbearance lending to low-quality borrowers. To this end, we address the measurement problem for bank balance sheet risk. We identify the credit supply and allocation effects of bank capital in the bank loan equation specified at loan level, thereby finding that the "parallel worlds", or the two opposing views, emerge because the regulatory capital does not reflect the actual condition of increased risk on bank balance sheet, while the market value of capital does. By uncovering banks' engagement in patching-up of the regulatory capital in the Japan's post-bubble period, we show that lowly market capitalized banks that had difficulty in building up adequate equity capital for their risk exposure decreased the overall supply of credits. The parallels world can emerge whenever banks are allowed to overvalue assets with their discretion, as in Japan' post-bubble period.
\end{abstract}

JEL classification: G01, G21, G28.

Keywords: bank capital structure; capital crunch; forbearance lending; loan-level data; uncertainty; bank risk taking.

* The authors especially thank Takashi Hatakeda, You Suk Kim, Yoshiaki Ogura, Arito Ono, Takeshi Osada, Michiru Sawada, Masahiko Shibamoto, Etsuro Shioji, and Kenta Toyohuku for valuable comments and discussions. The authors also acknowledge participants of the 2018 Asian Meeting of the Econometric Society, the 2018 Annual Meeting of the Nippon Finance Association, and the 2017 Autumn Annual Meeting of the Japan Society for Monetary Economics, and the Kansai Monetary Economics Workshop. The authors are grateful for grants-in-aid from the Ministry of Education and Science, Japan.

${ }^{\dagger}$ Correspondence to Hitoshi Inoue, Faculty of Economics, Sapporo Gakuin University, 11-banchi Bunkyodai, Ebetsu, Hokkaido, 069-8555, Japan, E-mail: inoue12@sgu.ac.jp, fax: +81-11-386-8113.

${ }^{\ddagger}$ Faculty of Economics, Konan University, Okamoto 8-9-1, Higashinada, Kobe, Zip 658-8501, Japan, e-mail: kiyotaka@center.konan-u.ac.jp, fax: +81-(0)78-435-2403.

$\S$ Bank of Japan, 2-1-1, Hongokucho, Nihonbashi, Chuo-ku, Tokyo, Zip 103-0021, Japan, e-mail: kouji.takahashi-2@boj.or.jp 
1. Introduction Among financial crises in developed economies, the one in Japan after the collapse of the bubble economy in the early 1990s was unprecedented in terms of the length and depth of the subsequent economic downturn. ${ }^{1}$ Debates about the reasons for Japan's prolonged stagnation have been raised accordingly (e.g., Motonishi and Yoshikawa (1999), Hayashi and Prescott (2002), and Hoshi and Kashyap (2004)), and the issue concerning the lending behavior of banks with impaired capitals has been one of the most plausible explanations, as the post-bubble period saw the malfunction of the banking system.

When a severely adverse shock hits the economy and many borrowers become insolvent, theoretically banks should face impaired capitals, irrespective of whether the bank capitals are evaluated for the regulatory or market values. Theoretical literature predicts two-types of lending behaviors of such impaired banks: one is stagnant lending in a capital crunch, and the other is forbearance lending. In the former type of lending, impaired banks that are subject to capital constraints decrease credits to borrowers, whether they are good or bad borrowers. ${ }^{2}$ On the other hand, in the latter type, the impaired banks conduct a window dressing to avoid the realization of capital losses and thus allocate more credits to insolvent borrowers, while hoping that they will improve. ${ }^{3}$ These two practices have different theoretical backgrounds, but they have often been accused of being the source of the prolonged stagnation experienced since the 1990s in Japan: the stagnant bank lending is well known in Japanese as kashishiburi, while the forbearance lending as oigashi.

The two opposing views to explain lending practices of impaired banks share the premise that the impaired banks worried much about the further deterioration of their balance sheet, but these opposing views sharply differ in explaining impaired bank's lending behavior: the stagnant lending in a capital crunch involves the issue of overall credit undersupply to all borrowers, while the forbearance lending involves the issue of credit allocation to low-quality

\footnotetext{
${ }^{1}$ See e.g., Hoshi (2001) for Japan's bubble economy and its collapse in the early 1990s.

${ }^{2}$ Bernanke and Lown (1991) define a credit crunch as "a significant leftward shift in the supply curve for loans, holding constant both the safe real interest rate and the quality of potential borrowers", and relate a credit crunch to a capital crunch, providing evidence on the US economic crisis in the early 1990s. The theoretical literature on a capital crunch includes Holmström and Tirole (1997), Calomiris and Wilson (2004), and Diamond and Rajan (2011).

3 The theoretical literature about the forbearance lending includes Diamond (2001), Caballero et al. (2008), and Bruche and Llobet (2014).
} 
borrowers. However, somehow, empirical literature has provided the mixed evidence supporting the two opposing views on the lending behavior of Japanese distressed banks in the post-bubble period, as in Peek and Rosengren (2005), Gan (2007), and Watanabe (2007). In this paper, we explore the reason that such a parallel world of distressed bank's lending behavior emerged in empirical investigations, particularly focusing on a misperception problem for bank balance sheet (bank default) risk.

Models of banking under asymmetric information have emphasized the potential conflict of interest between banks and depositors (see, e.g., Diamond (1984) and Calomiris and Wilson (2004)). This information problem faced by banks encourages them to offer shortterm (demandable) low-risk debt, concentrating most balance sheet risk in their capital and thus insulating depositors from the balance sheet risk. Therefore, it really matters that one can precisely grasp whether banks are well capitalized to absorb their balance sheet risk and stabilize banking system. In the post-bubble period of Japan, the misperception problem for bank balance sheet risk came in tandem with the introduction of regulatory capital standards, though they were introduced to prevent an overall undersupply of credit in a capital crunch or prevent excessive risk taking by impaired banks in the forbearance lending.

Figure 1 shows the bank market capital ratio and regulatory capital surplus in the post-bubble period of Japan. We can observe that the regulatory capital ratio continued to increase during the 1990s, while the market value of bank capital continued to decrease. This indicates that Japanese banks window-dressed the regulatory capital ratio, albeit facing substantive increases in their default risk measured by the market value. Indeed, the correlation of the two capital measures is -0.83 and hence they have a seemingly contradicting information on bank capital deficits. The post-bubble period in Japan saw the considerable divergence of the regulatory capital from its market value; thus it provides a good natural experiment which allows us to investigate whether or how such divergence between the bank regulatory and market capital affects our understanding of prevailing patterns of lending behavior of troubled banks. In particular, we address the coexistence problem for the two opposing views on the lending behavior of Japanese distressed banks in terms of the misperception problem for bank balance sheet risk, thereby demonstrating 
that the use of the regulatory capital as a measure of bank balance sheet risk would lead to erroneous assessment of bank lending behavior.

Our study for the misperception of bank balance sheet risk and lending behavior fully shares the awareness of recent empirical studies on the misperception problem for bank balance sheet risk before and after the 2008 financial crisis. Haldane (2014) and Bulow and Klemperer (2015) pointed out that regulatory measures of bank capital have not had predictive power for bank failures. Indeed, the regulatory measures of Bears Sterns, Wachovia, Washigton Mutual, Fannie Mae, and Freddie Mac were all seen by regulators as well capitalized immediately before their failures. Haldane and Madouros (2012) and Sarin and Summers (2016) attempted to measure bank risk through market measures, thereby demonstrating that in a horse race among regulatory measures (e.g., the Basel III Tier I ratio) and market measures (e.g., credit default swaps, and price-earnings ratios), the market capital ratio (the market value of equity relative to total assets) has most explanatory power in predicting bank failure. In addition, the market capital ratio of US major banks has declined not only in the precrisis period, but also in the current period (Sarin and Summers (2016)). These studies focused on the misperception problem for bank balance sheet risk. However, our study develop this issue by addressing the possibility that such misperception problem would cause erroneous assessment of bank lending behavior and would lead to the coexistence of the two opposing views about it, as in the late 1990s in Japan. Because the late 1990s in Japan is also the pre-banking crisis period as well as the post-bubble period, our analysis of this period would give a rich insight into the arrival of the banking crisis.

In this paper, to address the coexistence problem, we inspect a loan-level matched dataset of Japanese banks and their listed borrowers in the post-bubble period of the late 1990s, as in Peek and Rosengren (2005) and Gan (2007). This is partially because loanlevel data enable us to overcome the identification problem in terms of the controllability of demand factors in specifying the bank loan equation, and partially because testing the forbearance lending by lowly capitalized banks to their low-quality borrowers requires the inclusion of a firm performance variable in the bank loan equation. Loan-level data are superior to bank- and firm- level panel data in data structure to overcome the omitted- 
variable problem due to the weakness in controlling for borrower-side factors in the bank loan equation (see Khwaja and Mian (2008) and Jiménez et al. (2012; 2014)).

Our analytical focus is on the effect of changes in bank capital (the regulatory capital or the market capital) $\mathrm{BCAP}_{i t}$ on the "allocation" of bank credits $\Delta \operatorname{LOAN}_{i t}^{j}$ among good and bad borrowers as well as on the "supply" of credits to those borrowers. The novelty of our analysis is that we strictly define the credit supply and the allocation effect as the first and the second derivative effect in the bank loan equation specified at loan level. More concretely, the credit supply effect of bank capital involves the first derivative $\partial \Delta \mathrm{LOAN}_{i t}^{j} / \partial \mathrm{BCAP}_{i t}$ in the bank loan equation, where previous researches find the existence of a capital crunch mainly focused on, irrespective of whether it used loan-level (Gan (2007)), or bank-level data (Watanabe (2007)). On the other hand, the credit allocation effect involves a coefficient parameter on an interaction term consisting of bank capital ratios and a firm performance variable $\mathrm{FIRM}_{t}^{j}$, or the second derivative $\partial^{2} \Delta \mathrm{LOAN}_{i t}^{j} / \partial \mathrm{FIRM}_{t}^{j} \partial \mathrm{BCAP}_{i t}$, which Peek and Rosengren (2005) focused on to build the evidence that the forbearance lending prevailed in the Japan's post-bubble period using loan-level matched data.

If the first derivative has a positive value, it implies that a capital crunch, or the stagnant lending by lowly capitalized banks, prevailed in the post-bubble period, or the pre-crisis period, of the late 1990s. Conversely, if the first derivative has a negative value for lowquality borrowers and the second derivative has positive one (when a firm performance variable is defined so that its value become larger as the firm has better performance), the credit misallocation of lowly capitalized bank to low-quality borrowers prevailed. We focus on the sign of the two derivatives, especially considering whether or how the divergence of the regulatory capital from its market value produces the two opposing views on distressed banks' lending behavior.

We find that the use of the regulatory capital as a proxy of the bank balance sheet risk provides evidence supporting the forbearance lending in which lowly capitalized banks did not increase nor decrease credits, but the credits were allocated more to low-quality borrowers in the post-bubble period, as demonstrated by Peek and Rosengren (2005); that is, the regulatory capital produces an insignificant and a significantly positive estimate for the first and the second derivative, respectively. This result is observed only in the 
bank group with a higher level of the regulatory capital buffer, and accordingly, it is quite consistent with the hypothesis of Peek and Rosengren (2005) that Japanese banks engaged in window-dressing and patching-up of the regulatory or the bank capital ratio. Conversely, the use of the market value of bank capital provides evidence on the existence of a capital crunch in which lowly market capitalized banks decreased credits to all borrowers even if they were good borrowers, as demonstrated by Gan (2007) and Watanabe (2007), that is, the market capital produces a significantly positive and an insignificant estimate for the first and the second derivative. In contrast to the result for the regulatory capital measure, this result for the market measure is not qualitatively different among all the bank groups of lower, middle and higher levels of the market capital ratio, but quantitatively different so that equity capital constraints in lending are more pronounced for banks in the lower market capital group. The above findings are robust even if we employ the same type of nonlinear specification of Peek and Rosengren (2005) and we also use bank's lending exposure to real estates in the bubble period in stead of the market capital measure, as in Gan (2007) and Watanabe (2007).

Given the above findings, we uncover "the real world", or the true lending behavior of Japanese banks in the post-bubble (pre-banking crisis) period of the late 1990s. By simultaneously controlling for the two bank capital measures and their interaction effects in the bank loan model, we find that the supply and allocation effects (the first and second derivative effects) of the regulatory capital ratio completely vanish, but only the supply effect of the market capital ratio survives; that is, in reality, the stagnant lending due to a capital crunch prevailed, and not the forbearance lending. This result is robust, not depending on the use of some firm performance variables.

Why does only the effect of the market capital ratio survive, but not that of the regulatory capital ratio? To address this question, we run the cross-sectional regression for the bank capital structure, which is based on the standard corporate finance theory emphasizing "normal market forces": creditors require banks' capital building to secure a valuable charter or demand more equity protection from banks with more business uncertainty (see Flannery and Rangan (2008), Gropp and Heider (2010), Valencia (2016), and Corbae et al. (2017)). Through this capital structure regression, we find that the market capital ratio 
is determined by standard corporate finance variables, but the regulatory capital ratio is not at all. This result is robust, not depending on the levels of the two capital measures, though only the market capital ratio of banks with lower market capital levels - banks facing a more severe capital crunch - is less sensitive to two determinants: profitability and asset volatility. Such insensitivity implies that lowly market capitalized banks have difficulty to build up the market capital ratio in accordance with their profitability and uncertainty through issuing equity. Our findings from the capital structure regression suggest that in explaining bank lending behavior in relation to the capital structure, it would matter how the capital structure is determined. Without investigating it, we cannot identify the background mechanism, through which the capital structure affects banks' lending behavior.

Given this insight, a key driver of a capital crunch due to insufficient market capitalization would be the standard corporate finance determinants for the bank capital structure. Considering that banks with lower levels of the market capital ratio have more difficulty to build up sufficient equity capital, compared to their profitability and business uncertainty, we have the legitimate expectation that the inclusion both or either of the two determinants for the bank capital structure into the model would eliminate the significance of the market capital ratio in the bank loan equation. To examine this conjecture, we include, additionally, each of the determinants for the bank capital structure into the bank loan equation. Thus, we find that only the bank's business uncertainty, or the bank's portfolio risk, eliminates the significance of the market capital ratio. This implies that a key driver of a capital crunch would be rooted in lowly market capitalized banks' difficulty of building up appropriate level of equity capital for risks of their assets. This finding provides an rich insight into a background mechanism of a capital crunch: when they try to increase risk exposure and take more risk, if banks cannot build the market value of capital enough to absorb the risk, they will face equity capital constraints in lending. In addition, this tendency of a capital crunch is more noticeable for banks with lower market values of capital.

Our paper is organized as follows. Section 2 reviews previous literature on distressed banks' lending behavior and financial background in Japan, and then discusses the measure- 
ment problem for bank balance sheet risk. Section 3 presents an empirical specification and explains our dataset. Section 4 reports the results of our empirical analysis and then shows that the parallel worlds, or the two views on troubled bank's lending behavior, would emerge depending on which of the regulatory capital and the market capital is used as the proxy for bank balance sheet risk. Section 5 uncovers lending behavior by Japanese distressed banks through simultaneously controlling for the two capital measures and the interaction of them. In this section, we also explore the reason why the parallel worlds would emerge by investigating determinants of the two capital measures. Section 6 explores a key driver of the capital crunch among the determinants of the bank capital structure, thereby providing an insight for a background mechanism of the lending by troubled banks. Section 7 offers conclusions.

2. Bank Balance Sheet Risk and Lending Behavior In this section, we review literature on distressed banks' lending behavior and financial background in Japan, and then discuss the measurement problem for bank balance sheet risk in assessing those lending behavior.

2.1. Literature on Lending by Troubled Japanese Banks Here, we briefly review previous researches on the lending behavior of troubled Japanese banks, particularly focusing on what measures they used as a proxy of bank balance sheet risk or bank default risk. As discussed below, we place high priority on the three studies of Peek and Rosengren (2005), Gan (2007), and Watanabe (2007), partially because they allow us to highlight the measurement problem for bank balance sheet risk in analyzing distressed banks' lending behavior, and partially because like ours, the former two studies used loan-level matched data, though each provided two opposing views on distressed banks' lending behavior in the post-bubble (pre-banking crisis) period of Japan.

One strand of empirical researches on Japan's lending by distressed banks involves examining a capital crunch, or a debt overhang, in the post-bubble period of the 1990s. ${ }^{4}$ These recent studies include Gan (2007) and Watanabe (2007). The two studies used each

\footnotetext{
${ }^{4}$ See Bernanke and Lown (1991), Peek and Rosengren (1995; 2000), Berrospide and Edge (2010), and Carlson et al. (2013) for empirical researches on a capital crunch in the United States.
} 
bank's lending exposure to the real estate industry in the real-estate bubble of the late 1980s as a proxy of the bank balance sheet risk in the post-bubble period. Watanabe (2007) used bank-level panel data from 1995 to 2000 and used the lending exposure to the real estate industry as the instrument variable of the regulatory capital ratio, thus providing the evidence that a capital crunch existed in the late 1990s. ${ }^{5}$ Like us, Gan (2007) used loan-level matched data from 1994 to 1998, and thus demonstrated that lending by banks with greater real estate exposures in the late 1980s decreased more credits to borrowers due to a capital crunch of the late 1990s.

In contrast to the above studies supporting the existence of a capital crunch, Peek and Rosengren (2005) showed that banks' window-dressing motives to avoid the realization of losses on their balance sheet provided additional credit to low-quality firms in the postbubble period. Like ours, they used loan-level matched data from 1994 to 1999, and included the regulatory capital ratio as a proxy of bank balance sheet risk in their bank loan equation. In terms of the implementation of prudential policy, Giannettie and Simonov (2013) examined the effects of Japan's three public capital injections in 1998, 1999 and 2003 on capital-injected banks' lending behavior using loan-level data from 1998 to 2004. They demonstrated that if capital injected banks were still undercapitalized, those banks were more likely to lend to low-quality borrowers, using the regulatory capital ratio as a proxy of the bank balance sheet risk. ${ }^{6}$

\footnotetext{
${ }^{5}$ Using a bank-level panel dataset, Ito and Sasaki (2002) estimated a bank loan equation in Japan from 1990 to 1993, as did Woo (2003) from 1991 to 1997, Ogawa (2003, Chapter 2) from 1992 to 1999, Montgomery (2005) from 1982 to 1999, and Hosono (2006) from 1975 to 1999. They all found that a decrease in the regulatory capital ratio caused a decrease in bank loans in the 1990s by including the regulatory capital ratio into their bank loan equations. However, unlike Watanabe (2007) and Gan (2007), they all did not use an instrumental variable for the regulatory capital ratio such as the lending exposure to the real estate industry in the late 1980s; hence, their empirical results appear to be less robust and depend on sample periods to be used for their analyses.

${ }^{6}$ Unlike these two studies, Sekine et al. (2003) used firm-level panel data from 1986 to 1999, while Watanabe (2010) used bank-level panel data from 1995 to 2000 and then included bank's book capital ratio as a proxy of its balance sheet risk in his bank loan equation. The former found that highly-indebted firms belonging to nonmanufacturing industries increased bank borrowings after 1993, albeit their low profitability, and the latter demonstrated that tough regulatory stance which urged banks to write off nonperforming loans produced a large loss of bank capital and such a loss of capital would induce bank lending to shift to low-quality borrowers. Caballero et al. (2008) addressed a more specific issue of the misallocation of bank credit toward low-quality borrowers as "zombie lending" (see also Hoshi (2006)). They used firm-level panel data form 1981 to 2002, thereby demonstrating that the increase in the number of zombie firms would suppress the investment and employment growth of non-zombies.
} 
As reviewed above, previous researches have focused on Japan's bank lending behavior mainly in the late 1990s, and have provided the mixed evidence of the stagnant and the forbearance lending for the lending behavior of distressed banks. Through this paper, we hypothesize that such coexistence of the two opposing views would be ascribed to the difference in the choice of a proxy for bank balance sheet risk used to assess the lending behavior of troubled banks. The researches suggesting the existence of a capital crunch use banks' lending exposures to the real estate in the real-estate bubble of the late 1980s as a proxy of bank balance sheet risk in the post-bubble period, as in Gan (2007) and Watanabe (2007), while those suggesting the existence of the forbearance lending used the regulatory capital ratio, as in Peek and Rosengren (2005). One of possible reasons for such a measurement problem of the bank balance sheet risk in Japan is banks' behavior under the regulatory policy implemented after the introduction of the regulatory capital standards. In the next subsection, we review this problem in the context of Japan's bank regulatory policy.

2.2. Misperception Problem for Bank Balance Sheet Risk In the post-bubble period of Japan, or the pre-banking criss period, of the late 1990s, the measurement problem for bank balance sheet risk came in tandem with the introduction of the regulatory capital standard, although they are originally aimed at preventing the stagnant lending in a capital crunch or excessive risk taking by impaired banks in the forbearance lending.

In 1988, bank regulators in major industrial countries agreed to standardize capital requirements internationally, through the so-called Basel Accord. Subsequent to this, all Japanese banks struggled to meet these capital standards in the 1990s. During this period in Japan, land and stock prices fell continuously. Consequently, many loans granted during the bubble period of the late 1980s became nonperforming. Accordingly, banks that were more impaired and had less capital issued additional subordinated debt to inflate their bank capital. They were able to do so because, within the local Japanese rule governing capital requirements, subordinated debt can be counted as Tier II capital (see, e.g., Ito and Sasaki (2002) and Montgomery (2005)). Japanese banks also used deferred tax assets to compensate for capital losses arising from unrealized losses on their holding stocks. This is because the government allowed banks to include their deferred tax assets into Tier I 
capital in 1998. Bank managers at their discretion estimated subjectively the total amount of deferred tax assets (see Skinner (2008)).

In the 1990s, these regulatory forbearance policies had caused Japanese banks to engage in a "patching up" of their regulatory (that is, book) capital ratios (see, e.g., Shrieves and Dahl (2003)). In the late 1990s, the attitude of the Japanese government and regulatory authorities toward Japanese banks started to change by allowing them to enter bankruptcy and by conducting capital injections. In evidence, in 1998 and 1999, the government of Japan decided to infuse a large amount of capital into poorly capitalized banks in order to increase their capital adequacy ratios. These large-scale public capital injections allowed almost all Japanese banks to meet their capital standards (see, e.g., Watanabe (2007) and Nakashima (2016) for the Japanese bank recapitalization programs). However, the amount of nonperforming loans in Japanese banks only started to decrease after the Financial Revitalization Program, or the so-called Takenaka Plan, was executed in 2002 (see Sakuragawa and Watanabe (2009) for details).

Figure 1 shows the bank market capital ratio, which is defined by dividing the market value of bank's equities by its total book assets, and the regulatory capital surplus - defined as the difference between bank's reported capital adequacy ratio and its regulatory target ratio, i.e. $8 \%$ for international banks and $4 \%$ for domestic banks - in the post-bubble period of Japan. As shown in this figure, the regulatory capital ratio continued to increase during the 1990s because of the Japan's regulatory forbearance policies, while the market capital ratio continued to decrease because equity market participants considered that Japanese banks conducted window-dressing of their regulatory capital by overvaluing their capital and undervaluing their nonperforming loans (see Fukao [2003] and Hoshi and Kashyap $[2004 ; 2010])$. In fact, the correlation coefficient of the two variables is -0.83 at the aggregate level. This tendency that the market value of capital and the regulatory capital diverge from each other, reflecting different information on banks' risk profiles, is also clearly observed in Figure 2, where the two variables appear to be negatively correlated in the post-bubble period.

This tendency is also observed in the relation between banks' lending exposure to the real estate industry in the real-estate bubble of 1989 and the regulatory capital. The 
left panel on Figure 3 shows that the regulatory capital has little or no correlation with the bank lending exposure to the real estate industry, with the correlation coefficient of 0.06. On the other hand, as shown in the right panel on Figure 3, the market value of capital and the bank lending exposure to the real estate industry are negatively correlated with the correlation coefficient of -0.46 , indicating that bank market capital ratio reflects information on the bank lending exposure to the real estate industry in the real-estate bubble period. Given the decline in real estate prices in 1990s caused a deterioration of the bank capital, the negative correlation indicates that the market value of the bank capital are likely to capture the soundness of bank capital more correctly (see Gan [2007]) and Watanabe [2007]). In Subsection 5.2, to tackle the issue of why and how the two capital measures produce the two opposing views of troubled banks' lending behavior, we will examine determinants of the two measures in terms of the standard corporate finance theory emphasizing market forces.

Given that large Japanese banks received the capital injection programs around 2000, when the banking crisis occurred, the above discussion provides an insight on the measurement problem for bank balance sheet risk; that is, the market value of bank capital (or the bank lending exposure to the real estate industry) can capture bank default risk in the post-bubble period of the 1990s, while the regulatory capital cannot capture it because troubled Japanese banks were allowed to overvalue their portfolios with their partial discretion under the framework of the Basel Accords. As discussed in Introduction, this insight shares the finding of previous studies for the misperception problem for bank balance sheet (or bank default) risk before and after the 2008 financial crisis (Haldane and Madouros [2012] and Sarin and Summers [2016]), which demonstrated that the market capital ratio had outstandingly explanatory power in predicting bank failure before the crisis, but the regulatory capital ratio did not at all.

With due consideration of such a misperception problem for bank balance sheet risk, we can have the legitimate expectation that the conclusion of the lending behavior of distressed banks heavily depends on which of the two measures is used as a proxy of bank balance sheet risk. In the following, we will untangle this misperception problem for bank balance sheet risk and its lending behavior through analyzing the bank loan equation. 
3. Empirical Specification and Data In this section, we start by introducing an empirical specification for bank lending to examine the measurement problem for bank balance sheet and bank lending behavior, and then discuss estimation method and our dataset.

\subsection{Specification for Bank Loan Equations and Estimation Method As dis-} cussed in Introduction, we use a loan-level matched dataset of Japanese banks and their listed borrowers to identify the effect of bank capital on lending in Japan's post-bubble period, as in Peek and Rosengren (2005) and Gan (2007). The loan-level matched data allow us not only to control for borrower-side factors through time*firm fixed effects, but also to analyze the credit allocation effect through the interaction (second derivative) effect of bank capital and firm performance variables. To exploit these advantages of the loan-level matched data, we specify the bank loan equation as follows:

$$
\Delta \mathrm{LOAN}_{i t}^{j}=a_{0}+a_{1} \mathrm{BCAP}_{i t-1}+a_{2} \mathrm{BCAP}_{i t-1} * \mathrm{FIRM}_{t-1}^{j}+v_{i}+u_{j t}+\varepsilon_{i t}^{j},
$$

where the dependent variable, $\Delta \mathrm{LOAN}_{i t}^{j}$, indicates the growth rate of the total amount of loans outstanding between bank $i$ and domestic listed firm $j$ at time $t$. $v_{i}$ denotes bank $i$ 's time-invariant fixed effects to control for its time-invariant unobservables, while $u_{j t}$ denote firm $j$ 's time-varying fixed effects, or year $* u_{j}$ with time dummies (year), to control for borrowing firm's total demand factors at each sample period $t$. $\varepsilon_{i j t}$ indicates the stochastic disturbance term.

As for an observable explanatory variable, $\mathrm{BCAP}_{i t}$ denotes bank $i$ 's financial variable that is considered to well capture the adequacy of bank capital and the increase in bank default risk. More concretely, it includes either bank $i$ 's market capital ratio or regulatory capital surplus. ${ }^{7}$ FIRM $_{t}^{j}$ includes firm $j$ 's performance variable. In this paper, instead of using conventional measures for profitability such as the return on asset and the working

\footnotetext{
${ }^{7}$ As discussed in Subsection 2.2, the bank market capital ratio is defined by dividing market value of the bank's equity by its total book assets. We calculate the market value of equity by multiplying the end-of-year stock price by the number of shares. The regulatory capital surplus is defined as the difference between bank's reported regulatory capital ratio and its regulatory target ratio ( $8 \%$ for international banks and $4 \%$ for domestic banks).
} 
capital ratio, we use two equity-based measures of franchise values for firm's business performance in the future: Tobin's $q\left(\mathrm{FQ}_{t}^{j}\right)$ and the distance to default $\left(\mathrm{FDD}_{t}^{j}\right)$. The reason is that these equity-based measures would capture more firm's current and future profitability than the conventional profitability measures based on its past profit. Considering that banks tend to place more importance on borrower's future performance when they evaluate its default risk, the equity-based measures is more appropriate to examine their lending behavior. Tobin's $q$ is defined as the percentage ratio of the market value of firm $i\left(V_{A}\right)$ to its book value, where the market value of the borrowing firm is defined as the sum of the market value of its equity $\left(V_{E}\right)$ and the book value of its total liabilities $(D){ }^{8}$ The distance to default is defined as

$$
F D D=\left\{\ln \left(V_{A} / D\right)+\left(r-\frac{1}{2} \sigma_{A}^{2}\right)\right\} / \sigma_{A},
$$

where $r$ indicates the risk-free rate, and $\sigma_{A}$ indicates the volatility of firm assets. The distance-to-default can be interpreted as the expected standardized difference between the market value of the firm and the book value of its liabilities. If the difference is small (large), a firm is in danger of bankruptcy (healthy). A decrease (increase) in distanceto-default implies greater (lesser) credit risk. We define the volatility of firm asset $\sigma_{A}$ as $\sigma_{A}=\sigma_{E} \times V_{E} / V_{A}$. To estimate the volatility of equity $\left(\sigma_{E}\right)$, we calculate the standard deviation for the market value of equity for the final month of a firm's fiscal year and express the estimated volatility as annual rates. ${ }^{9}$ We use the yield on one-year JGB as a proxy of the risk-free rate $(r)$. In this paper, we mainly focus on estimation results obtained using Tobin's $q$ since it can easily classify borrowing firms as good or bad ones at the reference value of 100: if Tobin' $q$ is not less than 100, the borrowing firm is categorized as a good

\footnotetext{
${ }^{8}$ We calculate the market value of firm equity by multiplying the end-of-year stock price by the number of shares. Firm book value is the book value of total assets.

${ }^{9}$ More specifically, we calculate the annualized estimated volatility of the market value of equity as follows:

$$
\sigma_{E, i t}=\sqrt{\frac{1}{20-1} \times \sum_{k=d(t)-19}^{d(t)}\left(\operatorname{ret}_{k}-\overline{r e t_{d(t)}}\right)^{2} \times \sqrt{240}}
$$

where $d(t)$ denotes the last trading day of firm $i$ 's fiscal year $t$, ret $t_{k}$ denotes the daily rate of change in equity valuation, and $\overline{r e t_{d(t)}}$ is the average rate of change in equity valuation during the previous 20 days.
} 
borrower, and otherwise, as bad one. The equation additionally includes a lending exposure and a borrowing exposure as relationship variables. The lending exposure defined as loans from bank $i$ to firm $j$ divided by total loans of bank $i$. The borrowing exposure defined, in a same manner, as loans from bank $i$ to firm $j$ divided by total borrowings of firm $j$.

Note that to control for borrower-side factors in our bank loan equation with $u_{j t}$, we employ the fixed-effects approach proposed by Khwaja and Mian (2008) and Jiménez et al. (2012; 2014). The fixed-effects approach assumes that all potential borrower-side factors are embodied in time-varying firm unobservables, which are captured by time*firm fixed effects $\left(u_{j t}\right) \cdot{ }^{10}$ This approach enables us not only to specify our lending equation in more parsimonious way, as expressed in equation (1), but also to identify the effect of bank capital on lending more rigorously by controlling for demand factors in a more comprehensive way. In the following analyses, as the benchmark model, we use equation (1) where borrower-side factors are fully controlled with time*firm fixed effects .

On the other hand, by controlling for lender-side factors as well as borrower-side ones with the fixed-effects approach through time*bank fixed effects, one can focus on the interaction effects and handle the issue concerning credit allocation in a more robust way. More specifically, we introduce the following specification for bank loans:

$$
\Delta \mathrm{LOAN}_{i t}^{j}=a_{0}+a_{2} \mathrm{BCAP}_{i t-1} * \mathrm{FIRM}_{t-1}^{j}+v_{i t}+u_{j t}+\varepsilon_{i t}^{j},
$$

where we control for all potential lender-side factors by utilizing time-varying unobservables $v_{i t}$. We also examine the interaction effects, or the second derivative effect, on credit allocation using this double fixed-effect approach (see Jiménez et al. (2014) and Nakashima et al. (2017) for the double fixed-effect approach). ${ }^{11}$

Like ours, Peek and Rosengren (2005) and Gan (2007) used the loan-level matched

\footnotetext{
${ }^{10}$ Hosono and Miyakawa (2014), Nakashima (2016) employed this fixed-effect approach with Japanese loan-level matched data. Hosono and Miyakawa (2014) identified the effects of monetary policy on bank loan supply through the bank balance sheet channel, while the latter examines the effects of Japan's public capital injections on bank lending.

${ }^{11}$ Jiménez et al. (2014) and Nakashima et al. (2017) employed the double fixed-effect approach to identify a risk taking channel of monetary policy in bank lending, which involves the issue of whether or how monetary policy induces banks to change credit allocation from firms with lower credit risk to ones with higher credit risk.
} 
data, but their way of specifying the bank loan equation are different from ours. Peek and Rosengren (2005) transformed growth data of bank loans into binary outcome data, and then employed the random effect Probit model. Our choice of a linear rather than nonlinear model of bank lending is motivated by two reasons. First, nonlinear models tend to produce biased estimates in panel data sets with many fixed effects, leading to an incidental parameters problem and inconsistent estimates. Second, nonlinear fixed effects models generate biased estimates for interaction effects (see Ai and Norton (2003) for details). Nonetheless, we also employ their nonlinear specification, thereby attempting to conduct a robustness check for estimation results based on our linear specification. On the other hand, like ours, Gan (2007) specified a lending equation in a linear regression model, but unlike ours, did not control for bank's unobservables, and control for firm's unobservables through time-invariant fixed effects. ${ }^{12}$

Note that Peek and Rosengren (2005) included the regulatory capital surplus as a proxy for bank balance sheet risk and focused on the interaction terms of this bank financial variable and firm performance variables. On the other hand, instead of using the bank capital ratio, Gan (2007) included banks' lending exposures to the real estate industry in 1989 in order to identify loan supply effects of banks' impaired capital. In contrast to the two studies, Watanabe (2007) used a bank-level panel dataset and then used the lending exposure to real estates as the instrument variable of the regulatory capital ratio, thus providing the evidence that a capital crunch existed in the late 1990s. In Section 4, we also test these specifications for robustness check.

The advantage of our loan-level analysis based on equations (1) and (2) is that we can identify the credit supply and the allocation effect as the first and the second derivative effect. In these specifications, the first derivative, $\partial \Delta \mathrm{LOAN}_{i t}^{j} / \partial \mathrm{BCAP}_{i t-1}=a_{1}+a_{2} \mathrm{FIRM}_{t-1}^{j}$, captures the effect of bank capital changes on the credit supply, and the second derivative, $\partial^{2} \Delta \mathrm{LOAN}_{i t}^{j} / \partial \mathrm{FIRM}_{t}^{j} \partial \mathrm{CAP}_{i t}=a_{2}$, implies the bank capital effect on credit allocation among better- and worse-performing firms. If the first derivative has a positive value for all values of the firm performance variable $\mathrm{FIRM}_{t-1}^{j}$, it implies that a capital crunch prevails in

\footnotetext{
${ }^{12}$ She employed the Heckman (1979)'s two-stage regression approach and in the first-stage regression and then calculated the inverse Mills ratio to control for the survivorship bias for bank-firm relationships in the second-stage regression of her bank loan equation.
} 
a period of bank distress. On the other hand, if the first derivative has a negative value for low-quality firms (e.g. values with lower Tobin's $q$ ) and the second derivative has a positive value, the forbearance lending by lowly capitalized banks to low-quality firms prevails. We examine whether or how the two bank capital measures produce the two opposing views on distressed banks' lending behavior by focusing on the first and the second derivative effect, or the credit supply and the allocation effect of bank capital.

Our bank loan equations (1) and (2) are specified in the framework of the three-way fixed-effects linear regression model. To estimate our bank loan equation with the threeway fixed-effects, we employ the estimation method developed by Abowd et al. (1999) and Andrews et al. (2008). This estimation method gives consistent and unbiased parameter estimates not only for time-varying observables, but also unobserved fixed effects.

3.2. Data Set The empirical analysis developed in this paper rests on a loan-level dataset comprising a matched sample of Japanese banks and their borrowing firms listed in Japan. We construct our loan-level data based on the Corporate Borrowings from Financial Institutions Database compiled by Nikkei Digital Media Inc. This database annually reports short- (a maturity of one year or less) and long-term (a maturity of more than one year) loans from each financial institution for every listed company on any Japanese stock exchange.

The database includes some 120,000 observations, comprising more than 130 Japanese banks, 2,000 listed borrowing firms, and 17,000 relationships for our sample period from fiscal year (FY) 1992 to 1998, or the post-bubble period in Japan. The reason why we set up our sample period beginning from FY 1992 is that a set of minimum capital requirements for banks, known as Basel I, which was fully implemented at March 1993, or the end of FY 1992, in Japan. The reason why we end our sample period at FY 1998, or March 1999, is that important previous studies, such as Peek and Rosengren (2005) and Gan (2007), demonstrating the two opposing views - the stagnant lending in a capital crunch and the forbearance lending - focused on the post-bubble period since the early 1990s which saw the dysfunction of the Japanese banking system due to the severe deterioration of bank capital. We combined the Nikkei database with the financial statement data of the Japanese banks 
and their listed borrowing firms, also compiled by Nikkei Digital Media Inc. ${ }^{13}$

Our chief difficulty in working with the loan-level data was sorting through various bank mergers and restructuring in our data. We recorded the date of all bankruptcies and mergers that took place in the Japanese banking sector in our sample period. First, we should not whenever a bank ceases to exist in our data because of a bankruptcy, firms cease reporting that financial institution as a source of loans. If firms cease reporting a bank as a lender and we could not find any information on a bankruptcy or a merger of the lending bank, we filled in zero value as the outstanding mount of loans from the bank in our data. On the other hand, if we find evidence of a bankruptcy or merger of the bank and a firm has the outstanding amount of loans from the restructured bank before that event and from a surviving bank after that event, we calculate the growth rate of the loan from the restructured bank by considering as if the restructured bank made both of the loans. ${ }^{14}$ In order to calculate the loan growth of a restructured bank, we traced to it all banks that predated it. Thus, if banks A and B merged in year $t$ to form bank C, bank C's loans in year $t-1$ is set equal to the sum of the loans for banks A and B, and the growth rate of bank C's loans in year $t$ would be calculated accordingly.

Table 1 reports summary statistics for variables including the two bank capital variables and the firm performance variables of Tobin's $q$ and the distance to default.

4. Emergence of Parallel World In this section, we report estimation results for the two types of bank loan equations, each of which includes the regulatory capital ratio and the market capital ratio. Thus, we show that the use of the two different capital measures produces the two opposing views, or the parallel worlds, for lending by troubled banks: the stagnant lending by banks with equity capital constraints and the forbearance lending by banks engaging in patching up of the regulatory capital.

13 The end of fiscal year for Japanese banks is March 31, but this is not necessarily the case for borrowing firms. When combining the Nikkei database for loan-level data with the financial statement data of banks and their borrowing firms, we match bank-side information to borrower-side information in the same fiscal year.

14 As for exits of some firms from our loan-level dataset in the middle of our full-sample period, we cannot identify reasons for firm exit from our sample, including bankruptcy, management buyout, termination of all the firm's relationships, etc. Therefore, if a firm exits from the original data after year $t$, we drop an observation for the firm from our dataset in year $t$. Thus, if the firm's last observation in the original dataset is in $t$, our adjusted sample includes the firm's observations until year $t-1$. 
4.1. Credit Supply and Allocation Effects We start by reporting estimation results of the supply effect of bank capital on lending, or the first derivative effect defined as $\partial \Delta \mathrm{LOAN}_{i t}^{j} / \partial \mathrm{BCAP}_{i t-1}=a_{1}+a_{2} \mathrm{FIRM}_{t-1}^{j}$. Table 2 shows estimation results for the coefficient parameters, $a_{1}$ and $a_{2}$, and Figure 4 shows the average supply effects for good and bad borrowers where borrowing firms are classified into two groups as follows: if its Tobin' Q is not less than 100, the borrowing firm is labeled as a "good borrower", and otherwise, it is categorized as a "bad borrower". As for the distance to default, a firm whose distance to default is higher than the sample mean is categorized as a good borrower, and otherwise, as a bad one.

As shown in this figure, the use of the regulatory capital ratio provides a negative estimate for the average supply effect of a bad borrower with the Tobin's $q$ being 50, though insignificant. We also find that the regulatory capital ratio produces significantly positive estimates for good borrowers with the Tobin's $q$ having values of 125 or more. These results indicate that the decrease in the regulatory capital would increase credits to low-quality borrowers, while decreasing credits to good borrowers during the Japan's post-bubble period. When using the distance to default, we have insignificant estimates for firms facing higher default risk (whose distance to default are lower than two), but significantly positive estimates for firms facing relatively lower credit risk (whose distance to default are higher than four).

On the other hand, the use of the market capital ratio produces significantly positive values for both good and bad borrowers. Furthermore, the result does not depend on which of the Tobin's $q$ and the distance to default is included as a firm performance variable. This implies that the decrease in the market capitalization would decrease credits to all borrowers irrespective of borrows' risk.

Table 2 also presents estimation results for the credit allocation effect of bank capital, or the second derivative effect: $\partial^{2} \Delta \mathrm{LOAN}_{i t}^{j} / \partial \mathrm{FIRM}_{t-1}^{j} \partial \mathrm{BCAP}_{i t-1}=a_{2}$. This table shows the credit allocation effects for the double fixed effect model (2) as well as the baseline model (1).

We find that the regulatory capital ratio has significantly positive estimates in a robust manner as both the baseline and the double fixed effect model produce positive estimates. 
This indicates that banks with lower regulatory capital would allocate more credits to borrowers with the lower Tobin's $q$ or distance to default.

In contrast, the market capital ratio produces conflicting results; that is, the double fixed effect model has an insignificant estimate, while the baseline model has significantly negative one. This tendency does not change whether we use the Tobin' $q$ or the distance to default as a firm variable. Given that the double fixed effect model can control for both lender- and borrower-side factors more thoroughly, we should attach more importance to the insignificant estimate based on this model. Hence, we infer that the use of the market capital ratio would provide the evidence supporting the existence of a capital crunch, in which banks with decrease in the equity capital would equally decrease credits to all borrowers irrespective of borrowers' risk.

The above results are based on the linear specification, as expressed in equations (1) and (2). Table 3 reports estimation results obtained by employing the nonlinear specification of Peek and Rosengren (2005) on the upper panel (A): the probit model with borrowing firm's random effects. ${ }^{15}$ We can observe that even if we employ the nonlinear specification, our findings are robust: the use of the regulatory capital provides evidence supporting the forbearance lending, while the use of the market value of bank capital provides evidence on the existence of a capital crunch.

\subsection{Lending Exposures to Real Estates in the Bubble Period As discussed in} Subsection 2.1, Gan (2007) and Watanabe (2007) assume that bank lending exposures to the real estate industry in the Japan's bubble period has substantive information on Japanese banks' balance sheet risk in the post-bubble period. Table 3 also reports estimation results obtained using the bank lending exposures to the real estate in 1989 in stead of the two bank capital measures on the panel (B). ${ }^{16}$

Note that the estimation results based on the lending exposures to the real estate industry are qualitatively same as those obtained using the market capital ratio; that is, it produces significant and insignificant estimates for the credit supply (first derivative) and

\footnotetext{
${ }^{15}$ Note that Peek and Rosengren (2005) did not include lender-side unobservable covariates in their nonlinear model. This may be because they treated only borrower-side mergers in their data construction.

${ }^{16}$ In the specification including the lending exposures to real estates in the late 1980s, we do not include bank fixed effects since the bank exposure variable is not time-varying one.
} 
allocation (second derivative) effects, respectively. This implies not only that banks with larger exposures to the real estate industry in the bubble period were more likely to decrease credits to all borrowers, but also that the market capital ratio also has similar information on Japanese banks' lending behavior in the post-bubble period as the exposure to the real estate industry in the bubble period of the late 1980s. Given that the high exposure of banks to the real estate industry is considered as a cause for deterioration of their balance sheet in the post-bubble period and leads to Japan's banking crisis in the late 1990s, the market capital ratio appears a more appropriate indicator to capture the relation between the condition of the bank capital and banks' lending behavior.

\subsection{Bank Lending with High, Middle and Low Capital Ratios The capital}

crunch and the forbearance lending view involve the issue of how well or how less bank capital is built up. To incorporate this issue into our analysis, we cluster our loan-level sample into three subsamples for banks with high, middle and low capital ratios for each of the two capital ratios. To construct the three subsamples, we defines banks belonging to the first tertile (above 34th percentile), the middle tertile (34-67th percentile) and the bottom tertile (below 67th percentile) of all banks as high, middle and low capital banks, respectively. Tables 4 and 5 show estimation results on the bank loan equations for banks with the high, middle and low capital based on the market and regulatory capital ratio, respectively.

In Table 4, we find that estimated coefficients on the market capital ratio are significantly positive for all the three levels of the market capital ratio, but the estimated value (approximately two) for banks with the low level market capital are much larger than those for banks with the high and middle market capital, each having almost same value (approximately one). Also note that these results do not depend on the choice of the firm performance variables; the Tobin's $q$ and the distance to default.

As clearly shown in Table 5, estimation results for the regulatory capital ratio has quite different tendency from those for the market capital ratio: the interaction effect, or the credit allocation effect, has significantly positive estimates for banks with the high level of the regulatory capital ratio. Also note that the results based on the subsample regression for banks with the high regulatory capital ratio more sharply demonstrate the forbearance 
lending by those banks, compared with the results based on the full-sample regression. In addition, the market capital ratio of those high regulatory capital banks is much smaller than those of the two other bank groups in terms of the sample mean. These findings indicate that banks more engaging in the window-dressing and the patching-up of the regulatory capital provided more credits to a low-quality borrower while those banks were facing low market values of equity capital.

\subsection{Parallel Worlds of Japan's Post-bubble Period Summing up our estimation} results for the post-bubble period of the late 1990s, the use of the market capital ratio and the bank lending exposures to the real estate industry in 1989 provides the evidence supporting the existence of a capital crunch, in which banks with impaired capital decreased credits to firms irrespective of whether they were good or bad borrowers, as demonstrated by Gan (2007) and Watanabe (2007). The degree of capital constraints in bank lending is especially higher for lower market capital banks, but the evidence for the capital crunch is widely observed, without depending on levels of the market capital ratio. On the other hand, the use of the regulatory capital ratio provides the evidence supporting the existence of the forbearance lending, in which impaired banks increased credits to low-quality borrowers, allocating more credits to those firms, as demonstrated by Peek and Rosengren (2005). In contrast to the case of the market capital constraints, regulatory capital constraints in the forbearance lending is observed only for higher regulatory capital banks, which face lower market capital ratios. Also note that the above findings for the market and the regulatory capital measures do not depend on whether we adopt linear or nonlinear specifications. In the next section, we will explore the real world of lending by Japanese

distressed banks through simultaneously controlling for the two capital measures and the interaction of them in the bank loan equation.

5. Uncovering the Real World In this section, we reveal the real world of distressed bank's lending behavior by controlling the interaction of the two capital measures, or the source of the misperception of bank balance sheet risk, in the bank loan equation. Thus, we answer which of the two opposing views - the stagnant lending by equity constrained banks and the forbearance lending by banks with regulatory capital constraints - is more 
appropriate interpretation of the troubled bank's lending behavior in Japan's post-bubble period. Moreover, we explore determinants of the regulatory and the market capital ratio using cross-sectional regression for the bank capital structure based on the standard corporate finance theory emphasizing market disciplines as as its determinants. By doing so, we examine the reason that the parallel worlds of the two opposing views emerge.

\subsection{Simultaneous Control of the Two Bank Capital Ratios In this subsection,} we simultaneously control for the market and the regulatory capital ratio and the interaction of them, thereby examining which of the two capital measures has explanatory power to explain bank lending behavior. As shown in Figure 1, and as pointed out by the recent empirical studies of bank balance sheet risk (Haldane and Madouros (2012), Haldane (2014), Bulow and Klemperer (2015) and Sarin and Summers (2016)), highly negative correlations between the regulatory capital and the market value of equity capital are one of the evidence of the misperception problem of measuring bank balance sheet risk based on the regulatory capital ratio. Taking into account that such negative correlations would affect estimation results for bank loan equations and produce the two opposing views on troubled banks' lending behavior, we control for the source of misperception: the interaction of two capital measures. More concretely, we introduce the two interaction terms, $\operatorname{REGCAP}_{i t} * \mathrm{MARKETCAP}_{i t}$ and REGCAP $i t * \mathrm{MARKETCAP}_{i t} * \mathrm{FIRM}_{t}^{j}$. The double interaction term $\left(\right.$ REGCAP $_{i t} *$ MARKETCAP $\left._{i t}\right)$ and the triple term $\left(\right.$ REGCAP $_{i t} *$ MARKETCAP $_{i t} *$

$\mathrm{FIRM}_{t}^{j}$ ) are included to control for the interaction between the market capital and the regulatory capital ratio, and for the allocation effect through the interaction of the two capital measures, respectively. By including the two interaction terms into the bank loan equation in order to investigate the source of misperception, we control for the interaction effect of the two capital measures and thus address distressed bank's lending behavior in a more comprehensive way.

Tables 6 and 7 show estimation results obtained by simultaneously controlling for the two capital measures and the two interaction terms in bank loan equations (1) and (2). Tables 8 and 9 report results based on the subsample regressions for the high, middle and low levels of the market and the regulatory capital ratio. When using Tobin's $q$ as a firm performance variable in Tables 6 and 8, we show that the simultaneous inclusion of the 
two capital measures provides significant estimates for the two coefficients. However, the additional inclusion of the interaction terms eliminates the significance of the regulatory capital ratio. On the other hand, when using the distance to default as a firm variable in Tables 7 and 9, we find that the simultaneous inclusion of the two capital measures eliminates the significance of the regulatory capital ratio. Also note that these finding that the significance of the market capital ratio remains significant are robust as they do not depend on the levels of the market and the regulatory capital ratio. Given that the significance of the market capital ratio survives in a robust manner, bank lending behavior in Japan's post-bubble period, or pre-banking crisis period, of the late 1990s should be characterized as the stagnant lending by banks subject to equity capital constraints in a capital crunch, instead of the forbearance lending.

\subsection{Determinants of Market and Regulatory Capital Ratios In the previous} subsection, we demonstrated that the bank lending behavior in Japan's post bubble period would be characterized as a capital crunch in which banks with equity capital constraints decreased credits to borrowers irrespective of borrowers' risk. Here, we examine the reason that the two bank capital measures moved in the opposite direction and the two opposing views emerged. To this end, we analyze determinants of the market and the regulatory capital ratio, following the empirical analyses of Flannery and Rangan (2008) and Gropp and Heider (2010). These studies attempt to identify determinants of bank capital structures by examining cross-sectional regressions. Their econometric specification based on the corporate finance theory are as follows:

$$
\mathrm{BCAP}_{i t}=\alpha_{0}+\alpha_{1} \mathrm{BQ}_{i t-1}+\alpha_{2} \sigma_{i t-1}+\alpha_{3} \mathrm{PROF}_{i t-1}+\alpha_{4} \ln \mathrm{SIZE}_{i t-1}+\alpha_{5} \mathrm{COL}_{i t-1}+\epsilon_{i t},
$$

where BCAP indicates the regulatory or the market capital ratio. The explanatory variables are the bank's Tobin's $q$, or the bank charter value (BQ), the logarithmic value of the bank's asset volatility, or the bank's total risk exposure $(\sigma)$, profitability (PROF), the logarithmic value of total assets (SIZE) and collateral assets (COL). We include the bank's Tobin's $q$ and asset volatility defined in the same manner as the firm's Tobin's $q$ and asset volatility (see Subsection 3.1). We define the profitability as the return on asset in percentage terms 
and the collateral assets as $100 \times\left(\right.$ Liquid Assets + Tangible Assets)/Total Assets. ${ }^{17}$ The all variables are lagged by one year. The regression also includes time and bank fixed effects (year and $u_{i}$ ) to control for unobserved heterogeneity across time and the bank level that may be correlated with the explanatory variables. Table 10 reports summary statistics for those variables.

In Subsection 4.3, when using the market capital ratio as a measure of bank balance sheet risk, we found that banks with the lower market capital ratio were more severely capital constrained in lending than those with the middle and higher capital ratio, although all the Japanese banks faced a capital crunch. On the other hand, when using the regulatory capital ratio, we demonstrated that only banks with the higher regulatory capital engaged in forbearance lending. To incorporate these findings into our analysis of bank capital structure, we also estimate equation (4) by additionally including five interaction terms of the five explanatory variables and the lower market capital dummy in the regression for the market capital ratio, and the interaction terms between each of the explanatory variables and the higher regulatory capital dummy in the regression for the regulatory capital ratio. Thus, we provide a detailed explanation for the reason that one would have the two opposing evidence for troubled banks' lending behavior.

The explanatory variables in equation (4) are conventional ones to explain the capital structure on the basis of the standard corporate finance theory emphasizing market forces. ${ }^{18}$ According to this view, so-called the market view, the bank's Tobin's $q$ is expected to have positive estimates since banks would protect a valuable charter by lowering their leverage and thus by lowering default risk. Moreover, the bank profit would also have a positive coefficient as higher profits and sticky dividend allow to banks to accumulate capital. The bank's total risk exposure defined as its asset volatility also should have a positive estimate based on the inference that counterparties would claim more capital to banks with more risk taking and more business uncertainly. On the other hand, there is

\footnotetext{
17 More concretely, we define Liquid Assets as Total Securities + Treasury Bills + Other Bills + Bonds + CDs+Cash and Tangible Assets as Land and Buildings+Other Tangible Assets (see also Gropp and Heider $(2010))$.

18 The corporate finance theory for the capital structure documents the role of dividend. However, we do not include an indicator for dividend payers because all the banks pay dividends in our sample.
} 
no clear prediction on how the collateral and the size affect capital building in terms of the standard corporate finance theory. In contrast to the corporate finance view (or the market view), one of alternative views puts emphasis on the impact of the capital regulation. Hence, it predicts that the standard corporate finance determinants have little or no explanatory power because the market forces are not main driving forces for banks to build up their capital. The other alternative is the "buffer" view, where banks tend to hold capital buffers above minimum regulatory requirement levels to avoid the costs that arise from issuing equity on short notice. This buffer view predicts that banks with higher profits and higher Tobin's $q$ are likely to be more leveraged because such banks would face less asymmetric information problems, and their costs associated with issuing equity are relatively small.

Table 11 shows results for the regression of the market and the regulatory capital ratio. In this table, we can observe that the two capital ratios provide quite different results, which well characterize capital building behavior by Japanese banks in the late 1990s. More concretely, the standard corporate finance variables significantly determine the market capital ratio, while none of them determines the regulatory capital ratio. This means that during the post-bubble period, or the pre-banking crisis period of the late 1990s, banks' equity capital reflected normal market forces, but its regulatory capital did not at all. In other words, in that period, neither the market view nor the buffer view is applied to the regulatory capital ratio.

The significantly positive estimate for the bank's Tobin's $q$ (BQ) indicates that the market capital ratio is associated with the bank's charter value, or its future cash flows, while the regulatory capital ratio is not. Given that the sample mean of the regulatory capital ratio continued to increase, but that of the market capital ratio continued to decrease during the late 1990s, we can infer that Japanese banks were not able to maintain the market capital to protect a valuable charter with the deteriorating Japanese economic conditions while they were able to somehow increase the regulatory capital, irrespective of the decreasing charter value. ${ }^{19}$ In other words, as the charter value decreases, banks tend

\footnotetext{
19 In the late 1990s, low banks' profits also contributed to the decrease in the market capital ratio.
} 
to become more leveraged (see Calomiris and Nissim (2014) for the US banks). ${ }^{20}$

The positive estimate of the bank's total risk exposure $(\sigma)$ suggests that Japanese banks were substantially subject to the market forces: counterparties demanded more equity protection from a bank with greater portfolio risk (Flannery and Rangan (2008), Valencia (2016), and Corbae et al. (2017)). However, banks facing higher business uncertainly were not able to build up equity capital during the post-bubble period. Indeed, as shown in Figure 5, the market capital ratio continued to decrease during Japan's pre-banking crisis period of the late 1990s, while the level of the bank's asset volatility remained stable. By contrast, the insignificant estimate of the regulatory capital ratio implies that a Japanese bank built up regulatory book capital without being exposed to market forces. The estimation results for the Tobin's $q$ and the risk exposure highlight the difference in the market and regulatory capital ratios in terms of the market disciplines.

However, even in the regression of the market capital ratio, the Tobin's $q$ and the bank's total risk exposure have different tendency for their estimation results, depending on whether a bank enters into the lower market capital group or not. More concretely, the interaction term of the Tobin's $q$ and the lower market capital dummy does not have significant estimates, whereas that of the bank's risk exposure has significantly negative estimates, implying that the market capital ratio of the lower market capital banks less reflect their portfolio risk. This is primarily because such banks were not able to issue equity and increase market cap, even if they faced larger portfolio risk or tried to take more risk.

Estimation results for the other explanatory variables in the market capital equation are also quite consistent with the corporate finance theory and previous research on bank capital structure (Flannery and Rangan (2008) and Gropp and Heider (2010)), but those in the regulatory capital equation are not. Also note that such insensitivity of the regulatory capital to the conventional explanatory variables are observed in all Japanese banks with the lower, middle and higher levels of the regulatory capital.

We find that the profitability (PROF) has a significantly positive estimate for the market

\footnotetext{
${ }^{20}$ Calomiris and Nissim (2014) examined declines in the US bank's Tobin's $q$ after the financial crisis and showed that the declines would reflect the erosion of future profits.
} 
capital ratio as Tobin's $q$ does, indicating that banks tend to accumulate profits to increase the market capitalization (see Berger (1995)) with view to maintaining a valuable charter. However, for banks with the lower market capital ratio, the profitability less affects the market capital than for those with higher market capital. This patter is observed in the estimates for the bank assets risk measure but not for the Tobin's $q$. One of the possible reasons for the heterogeneity in their impacts on the market capital is that banks with lower market capital are more likely to face lower equity values and consequently they have the difficulty of issuing equity in spite of high volatility in their assets. Thus, their market capital turns to be less sensitive to their total risk exposure and profits. Another explanation for the heterogeneity in the impacts of profits is that the "buffer" view start to become effective as banks' market capital ratios decrease: i.e., banks with lower capital make efforts to find a way to increase their capital as a buffer with their profits decreasing, which weaken the positive association with bank market capital.

The bank size (SIZE) and the collateral asset (COLL) have significantly positive estimates for the regression of the market capital ratio, and the results do not depend on its capital level since the interaction effects are not significant. The positive estimate for the bank size imply that larger banks would hold more equity capital, but the regulatory capital was built up irrespective of bank size. The positive estimate of the collateral asset (COLL) in the market capital equation implies that the increase in banks' collateral assets would induce them to increase their market capitalization. This is probably because such an increase in banks' collateral assets is favored by market participants and thus larger amounts of collateral maybe contribute to banks' market capital.

Summing up our estimation results, the mechanism of determining the market and the regulatory capital ratio is quite different. The normal market forces measured by the explanatory variables based on the standard corporate finance - the charter value, the uncertainty, the profitability, the bank size and the collateral asset - matter in differentiating the mechanism of the two bank capital measures. The market capital ratio is substantially subject to the normal market forces, but the regulatory capital ratio is not. Furthermore, for banks with low market capital, their profits and assets risk have less significant effects on the market capital although the bank Tobin's $q$ has almost same magnitude of the effect 
across banks with different market capital levels. This result suggests that in the Japanese late 1990s, although such banks struggled to increase market capital while facing a low charter value, low profits and high assets volatility, their market capital continued to decline as their evaluation in the capital market deteriorated. On the other hand, Japanese banks built the regulatory capital, utterly independently of the market forces. This is probably because as discussed in Subsection 2.1, the regulatory forbearance policy in Japan's post-bubble period allowed Japanese banks to engage in window dressing and patching up of the regulatory (that is, book) capital by overvaluing assets.

\subsection{The Real Wold of Japan's Post-bubble Period By simultaneously controlling}

for the market and regulatory capital ratios and the interaction of the two capital measures in the bank loan equations, we demonstrated that the significance of the regulatory capital ratios vanishes, but the the significance of the market capital ratio survives. Moreover, these results are robust even if we group Japanese banks into those with lower, middle and higher levels of the market and the regulatory capital ratio and then run the subsample regressions. These indicate that in reality, the Japanese distressed bank's lending behavior should be described as the stagnant lending in a capital crunch, but not as the forbearance lending. In particular, banks with the lower level of the market capital ratio were more severely subject to equity capital constraints in the capital crunch.

We also identified determinants of the market and regulatory capital of Japanese banks and thereby examined why the two seemingly parallel worlds of the distressed banks' lending would emerge, depending on which of the two bank capital measures is used in the bank loan equations. Surprisingly, all the standard corporate finance variables do not explain Japanese banks' regulatory capital, while they well explain their market capital. This implies that Japanese banks engaged in patching up of their regulatory capital at their discretion under the regulatory forbearance policy, utterly independently of the normal market forces. On the the other hand, while banks engaged in window dressing of the regulatory (or book) capital, the market capital ratio of Japanese banks was substantively affected by the normal market forces. That is, as banks can build up the regulatory capital at their discretion, or there is a room for arbitrage in building up the regulatory capital, the determinant of bank lending is the market capital, which is evaluated by equity market 
participants and depositors, and thus is exposed to the normal market forces.

As discussed above, Japanese banks faced the capital crunch. In particular, banks in the lower market capital group were more severely subject to equity capital constraints in lending. We demonstrated that the market capital ratio of such banks was less sensitive to their portfolio risk and profitability. This finding implies that the stagnant bank lending in a capital crunch would worsen in the situation where counterparts require more equity protection from the lower market capital banks, but those banks are not able to build up adequate capital relative to portfolio risk and profitability. In the next section, we will examine the relation between capital crunch and determinants of capital in more details.

6. A Key Driver of the Real World In this section, we estimate the bank loan model by additionally controlling for the determinants of the market capital ratio - not only the two corporate finance variables, but also the other three variables - in order to find a key driver of a capital crunch.

\subsection{Controlling for Determinants of Market Capital Ratios Here, we report}

estimation results for the bank loan equation including not only the market capital ratio, but also the five explanatory variables, each included in the regression of the market capital ratio (see Subsection 5.2). The purpose of this test is to explore a key driver of a capital crunch by examining which of the five determinants of the market capital ratio eliminates the significance of the market capital ratio. ${ }^{21}$ If one of the determinants supersedes the market capital ratio, it is a key driver of a capital crunch. Table 12 reports estimation results obtained by additionally including the five determinants of the market capital ratio.

We can observe that only the bank's portfolio risk, or the bank's total risk exposure, eliminates the significance of the market capital ratio and it has a significantly positive estimate. Note that not only the portfolio risk, but also the profitability has less explanatory power for the market capital ratio of lowly market capitalized banks (see Subsection 4.3). However, the profitability appearers not to supersede the market capital ratio in the bank

\footnotetext{
${ }^{21}$ We do not include the interaction term of the market capital ratio and the firm performance variablethe borrower's Tobin' $q$ and the distance to default - since the interaction effect was not significant in a statistically robust manner, as demonstrated in Section 4.
} 
loan equation. This indicates that the difficulty of increasing capital due to high asset risks, rather than low profitability, is a main factor that caused a capital crunch.

7. Conclusion We provide three substantive conclusions. First, the misperception of bank balance sheet risk would lead to the misunderstanding of distressed banks' lending behavior by generating a "parallel world." This problem of misunderstanding exacerbates when a proxy for bank balance sheet risk has no information on the bank balance sheet risk, as in the Japanese economy in the late 1990s. The use of the regulatory capital, which reflect neither bank balance sheet risk nor normal market forces, provides the evidence supporting the forbearance lending in which lowly capitalized banks allocated more credits to low-quality borrowers, as demonstrated by Peek and Rosengren (2005). On the other hand, the use of the market value of bank capital, which correctly reflects bank balance sheet risk and normal market forces, provides the evidence supporting the existence of a capital crunch in which lowly capitalized banks decreased credits to all borrowers even if they were good borrowers, as demonstrated by Gan (2007) and Watanabe (2007). These results are robust even if we employ the same type of nonlinear specification of Peek and Rosengren (2005) and if we use each bank's lending exposure to real estates in the bubble period in stead of the market capital measure, as in Gan (2007) and Watanabe (2007).

Second, we find that the "real world" of distressed banks' lending behavior should be elucidated in terms of whether a proxy of bank balance sheet risk correctly reflect normal market forces emphasized in the literature of the capital structure: creditors demand more equity from banks with greater uncertainty to secure a valuable charter. By simultaneously controlling for the regulatory and market capital ratio, and the interaction of them in the bank loan equation, we demonstrated that only the coefficient of thev market capital ratio, which is determined by the normal market forces, remained significant in a robust manner. This indicates that distressed Japanese banks' lending behavior should be characterized as the stagnant lending in a capital crunch, but not the forbearance lending.

Lastly, banks facing lower market capital levels and more severe equity capital constraints in lending are less sensitive to the normal market forces because such lowly capitalized banks are more difficult to maintain enough equity capital relative to their total risk exposure and business uncertainty. In other words, a capital crunch would attributable 
to uncertainty faced by lowly capitalized banks and their difficulty of building up equity capital.

Our findings suggest that the "parallel worlds," or the two opposing views on lending behavior of troubled banks, emerge as the regulatory capital does not reflect the actual condition of increased risk on bank balance sheet, while the market capital does. In Japan's post-bubble period, banks with lower market capital levels decreased the supply of credits, engaging in patching up of the regulatory capital (i.e. book capital) under the regulatory forbearance policy. Such a capital crunch and regulatory arbitrage can occur simultaneously whenever a bank is allowed to overvalue its portfolios and capital with its partial discretion, though it shows up in the Japan's post-bubble (pre-banking crisis) period as one of the most typical cases (see also e.g., Haldane and Madouros (2012) and Sarin and Summers (2016) for the US case).

In the stagnant lending due to a capital crunch, distressed banks with impaired capital decrease credits whether their borrowing firms are low-quality or not. To the contrary, in the forbearance lending, such distressed banks do not decrease credits, but allocate more credits from good borrowers to bad borrowers. In other words, the forbearance lending has a certain aspect of the risk taking by the distressed banks on the future revival of low-quality borrowers (see Fukuda and Nakamura (2008)), but in the stagnant lending in a capital crunch, distressed banks are involved in the process of credit contraction not only for bad borrowers, but also for good borrowers. From this viewpoint, a capital crunch is in a more urgent situation for policy makers, where restoring banks' impaired capitals would bring about substantial improvements to economy. If one uses the regulatory capital in specifying the bank loan equation in spite of its weak tie with the bank balance sheet risk, it would lead policy makers to conduct a wrong policy based on the misunderstanding of distressed banks' lending behavior. In other words, our results suggest that it is important to consider the policy design so that banks are required to build up capital based on a substantive measure, but not spurious one.

\section{REFERENCES}


[1] Abowd, J., F. Kramarz, and D. Margolis, 1999, High Wage Workers and High Wage Firms, Econometrica, 67, 251-334.

[2] Ai, C., and E. Norton, 2003, Interaction Terms in Logit and Probit Models, Economic Letters, 80, 123-129.

[3] Andrews, M., L. Gill, T. Schank, and R. Upward, 2008, High Wage Workers and Low Wage Firms: Negative Assortative Matching or Limited Mobility Bias? Journal of the Royal Statistical Society, Series A, 171, 673-697.

[4] Bernanke, B., and C. Lown, 1991, The Credit Crunch, Brookings Papers on Economic Activity, 2, 205-239.

[5] Berrospide, J., and R. Edge, 2010, The Effects of Bank Capital on Lending: What Do We Know, and What Does it Mean? International Journal of Central Banking, 6, $5-54$.

[6] Bruche, M., and G. Llobet, 2014, Preventing Zombie Lending, Review of Financial Studies, 27, 923-956.

[7] Bulow, J., and P. Klemperer, 2015, Equity Recourse Notes: Creating Counter-Cyclical Bank Capital, Economic Journal, 125, 131-157.

[8] Caballero, R., T. Hoshi, and A. Kashyap, 2008, Zombie Lending and Depressed Restructuring in Japan, American Economic Review 98, 1943-1977.

[9] Calomiris, C., and B. Wilson, 2004, Bank Capital and Portfolio Management: The 1930's "Capital Crunch" and the Scramble to Shed Risk, Journal of Business, 77, $421-455$.

[10] Calomiris, C., and D. Nissim, 2014, Crisis-Related Shifts in the Market Valuation of Banking Activities, Journal of Financial Intermediation, 23, 400-435.

[11] Carlson, M., H. Shan, and M. Warusawitharana, 2013, Capital Ratios and Bank Lending: A Matched Bank Approach, Journal of Financial Intermediation, 22, 663-687. 
[12] Corbae, D., P. D'Erasmo, S. Galaasen, and A. Irarrazabal, 2017, Structural Stress Tests, mimeo.

[13] Diamond, D., 2001, Should Banks be Recapitalized?, Federal Reserve Bank of Richmond Economic Quarterly, 87, 71-96.

[14] Diamond, D., and R. Rajan, 2011, Fear of Fire Sales, Illiquidity Seeking, and Credit Freezes, The Quarterly Journal of Economics, 126, 557-591.

[15] Fukuda, S., and J. Nakamura, 2011, Why Did "Zombie" Firms Recover in Japan?, The World Economy, 34, 1124-1137.

[16] Gan, J., 2007, The Real Effects of Asset Market Bubbles: Loan- and Firm-Level Evidence of a Lending Channel, The Review of Financial Studies, 20, 1943-1973.

[17] Giannetti, M., and A. Simonov, 2013, On the Real Effects of Bank Bailouts: Microevidence from Japan, American Economic Journal: Macroeconomics, 5, 135-167.

[18] Haldane, A., 2014, Constraining Discretion in Bank Regulation, In: Goodhart, C., D. Gabor, J. Vestergaard, and I. Erturk, (Eds.), Central Banking at a Crossroads: Europe and Beyond, Anthem Press, London.

[19] Haldane, A., and V. Madouros, 2012, The Dog and the Frisbee, In Economic Policy Symposium Proceedings: The Changing Policy Landscape, Jackson Hole, Wyo.: Federal Reserve Bank of Kansas City.

[20] Hayashi, F., and E. Prescott, 2002, The 1990s in Japan: A lost decade, Review of Economic Dynamics, 5, 206-235.

[21] Holmström, B., and J. Tirole, 1997, Financial Intermediation, Loanable Funds and The Real Sector, The Quarterly Journal of Economics, 112, 663-691

[22] Hoshi, T., 2001, What Happened to Japanese Banks?, Monetary and Economic Studies, 19, 1-29.

[23] Hoshi, T., 2006, Economics of the Living Dead, The Japanese Economic Review, 57, 30-49. 
[24] Hoshi, T., and A. Kashyap, 2004, Japan's Financial Crisis and Economic Stagnation, Journal of Economic Perspective, 18, 3-26.

[25] Hoshi, T., and A. Kashyap, 2010, Will the U.S. Bank Recapitalization Succeed? Eight Lessons from Japan, Journal of Financial Economics, 97, 398-417.

[26] Hosono, K., 2006, The Transmission Mechanism of Monetary Policy in Japan: Evidence from Banks' Balance Sheets, Journal of the Japanese and International Economies, 20, 380-405.

[27] Hosono, K., and D. Miyakawa, 2014, Business Cycles, Monetary Policy, and Bank Lending: Identifying the Bank Balance Sheet Channel with Firm-bank Match-level Loan Data, mimeo.

[28] Ito, T., and Y. Sasaki, 2002, Impacts of the Basel Capital Standard on Japanese Banks, Journal of the Japanese and International Economies, 16, 372-397.

[29] Jiménez, G., S. Ongena, J. Peydró, and J. Saurina, 2012, Credit Supply and Monetary Policy: Identifying the Bank Balance-sheet Channel with Loan Applications, American Economic Review, 102, 2301-2326.

[30] Jiménez, G., S. Ongena, J. Peydró, and J. Saurina, 2014, Hazardous Times for Monetary Policy: What Do Twenty-Three Million Bank Loans Say About the Effects of Monetary Policy on Credit Risk-Taking?, Econometrica, 82, 463-506.

[31] Khwaja, A., and A. Mian, 2008, Tracing the Impact of Bank Liquidity Shocks: Evidence from an Emerging Market, American Economic Review, 98, 1413-1442.

[32] Montgomery, H., 2005, The Effect of the Basel Accord on Bank Portfolios, Journal of the Japanese and International Economies, 19, 24-36.

[33] Motonishi, T., and H. Yoshikawa, 1999, Causes of the Long Stagnation of Japan During the 1990s: Financial or Real? Journal of the Japanese and International Economies, $13,181-200$. 
[34] Nakashima, K., 2016, An Econometric Evaluation of Bank Recapitalization Programs with Bank- and Loan-level Data, Journal of Banking and Finance, 63, 1-24.

[35] Nakashima, K., M. Shibamoto, and K. Takahashi, 2017, Risk Taking Channel of Unconventional Monetary Policies in Bank Lending, mimeo.

[36] Ogawa, K., 2003, Economic Analysis of the Great Recession (In Japanese: Daifukyo no Keizai Bunseki), Nikkei Inc., Tokyo.

[37] Peek, J., and E. Rosengren, 1995, The Capital Crunch: Neither a Borrower nor a Lender Be, Journal of Money, Credit and Banking, 27, 625-638.

[38] Peek, J., and E. Rosengren, 2000, Collateral Damage: Effects of the Japanese Bank Crisis on Real Activity in the United States, American Economic Review, 90, 30-45.

[39] Peek, J., and E. Rosengren, 2005, Unnatural Selection: Perverse Incentives and the Allocation of Credit in Japan, American Economic Review, 95, 1144-1166.

[40] Sakuragawa, M., and Y. Watanabe, 2009, Did the Japanese Stock Market Appropriately Price the Takenaka Financial Reform?, In: Ito, T. and A. Rose, (Eds.), Financial Sector Development in the Pacific Rim, East Asia Seminar on Economics, University of Chicago Press, Chicago.

[41] Sarin, N., and L. Summers, 2016, Understanding Bank Risk through Market Measures, Brooking Papers on Economic Activity, 2, 57-109.

[42] Sekine, T., K. Kobayashi, and Y. Saita, 2003, Forbearance Lending: The Case of Japanese Firms, Monetary and Economic Studies, 21, 69-92.

[43] Shrieves, R., and D. Dahl, 2003, Discretionary Accounting and the Behavior of Japanese Banks under Financial Duress, Journal of Banking and Finance, 27, 12191243.

[44] Skinner, D., 2008, The Rise of Deferred Tax Assets in Japan: The Case of the Major Japanese Banks, Journal of Accounting and Economics, 46, 218-239. 
[45] Valencia, F., 2016, Bank Capital and Uncertainty, Journal of Banking and Finance, $69,51-59$.

[46] Watanabe, W., 2007, Prudential Regulation and the Credit Crunch: Evidence from Japan, Journal of Money, Credit and Banking, 39, 639-665.

[47] Watanabe, W., 2010, Does a Large Loss of Bank Capital Cause Evergreening?, Journal of the Japanese and International Economies, 24, 116-136.

[48] Woo, D., 2003, In Search of "Capital Crunch": Supply Factors behind the Credit Slowdown in Japan, Journal of Money, Credit and Banking, 35, 1019-1038. 
Table 1: Summary statistics for bank loan equations

\begin{tabular}{lccccc}
\hline \multicolumn{1}{c}{ Variable } & Obs. & Mean & Std. Dev. & Min. & Max. \\
\hline Dependent variables & & & & & \\
growth rate of loans $\left(\Delta \mathrm{LOAN}_{i t}^{j}\right)$ & 120561 & -2.146 & 27.594 & -99.852 & 100 \\
loan dummy & 120561 & .247 & .431 & 0 & 1 \\
& & & & & \\
Bank capital variables $\left(\mathrm{BCAP}_{i t-1}\right)$ & 119384 & 6.434 & 3.315 & .602 & 15.723 \\
market capital ratio & 120561 & 1.503 & 1.111 & -5.01 & 9.48 \\
regulatory capital ratio & 120534 & 9.285 & 3.79 & 2.865 & 30.667 \\
lending exposure to real estate & & & & & \\
& & & & \\
Firm performance variables $\left(\mathrm{FIRM}_{t-1}^{j}\right)$ & & & & \\
Tobin's $q$ (FQ & & & & \\
distance to default $\left(\mathrm{FDD}_{t-1}^{j}\right)$ & 118643 & 126.399 & 37.563 & 41.436 & 892.367 \\
& & 4.189 & 2.623 & .625 & 134.772 \\
Relationship variables & & & & & \\
lending exposure & 120561 & .034 & .093 & 0 & 1.987 \\
borrowing exposure & 120561 & 8.803 & 158.361 & 0 & 44065.18 \\
\hline \hline Notes: Estimation
\end{tabular}

Notes: Estimation samples are from March 1994 to March 1999. Lagged variables, or all explanatory variables, are from March 1993 to March 1998. We exclude the upper five percentiles of the growth rate of loans outstanding as the extreme values. The loan dummy is defined as one if $\triangle \mathrm{LOAN}$ is positive, zero otherwise. 
Table 2: Results on estimating bank loan equations

\begin{tabular}{|c|c|c|c|c|c|c|c|c|c|}
\hline \multirow[b]{3}{*}{$\mathrm{BCAP}$} & \multirow[b]{3}{*}{$a_{1}$} & \multicolumn{4}{|c|}{ regulatory capital } & \multicolumn{4}{|c|}{ market capital } \\
\hline & & (1) & $(2)$ & $(3)$ & (4) & (5) & (6) & $(7)$ & $(8)$ \\
\hline & & $\begin{array}{l}-0.495^{*} \\
(0.273)\end{array}$ & & $\begin{array}{c}0.123 \\
(0.145)\end{array}$ & & $\begin{array}{c}0.418^{* * *} \\
(0.111)\end{array}$ & & $\begin{array}{c}0.271^{* * *} * \\
(0.0789)\end{array}$ & \\
\hline $\mathrm{BCAP} \cdot \mathrm{FQ}$ & $a_{2}$ & $\begin{array}{c}0.00681^{* * *} \\
(0.00216)\end{array}$ & $\begin{array}{c}0.00467^{* *} \\
(0.00223)\end{array}$ & & & $\begin{array}{c}-0.00155^{* *} \\
(0.000633)\end{array}$ & $\begin{array}{c}0.000287 \\
(0.000641)\end{array}$ & & \\
\hline $\mathrm{BCAP} \cdot \mathrm{FDD}$ & $a_{2}$ & & & $\begin{array}{l}0.0484^{*} \\
(0.0293)\end{array}$ & $\begin{array}{c}-0.00460 \\
(0.0312)\end{array}$ & & & $\begin{array}{l}-0.0151^{*} \\
(0.00905)\end{array}$ & $\begin{array}{c}-0.0120 \\
(0.00921)\end{array}$ \\
\hline lending exposure & & $\begin{array}{c}6.173^{* * *} * \\
(0.883)\end{array}$ & $\begin{array}{c}6.253^{* * * *} \\
(0.886)\end{array}$ & $\begin{array}{c}6.167 * * * \\
(0.883)\end{array}$ & $\begin{array}{c}6.250 * * * \\
(0.887)\end{array}$ & $\begin{array}{c}6.799 * * * \\
(0.893)\end{array}$ & $\begin{array}{c}6.901 * * * \\
(0.902)\end{array}$ & $\begin{array}{c}6.776^{* * *} \\
(0.893)\end{array}$ & $\begin{array}{c}6.919^{* * *} * \\
(0.902)\end{array}$ \\
\hline borrowing exposure & & $\begin{array}{l}0.0223^{* *} \\
(0.00933)\end{array}$ & $\begin{array}{l}0.0192^{* *} \\
(0.00933)\end{array}$ & $\begin{array}{l}0.0223^{* *} \\
(0.00932)\end{array}$ & $\begin{array}{l}0.0192^{* *} \\
(0.00933)\end{array}$ & $\begin{array}{l}0.0216^{* *} \\
(0.00933)\end{array}$ & $\begin{array}{l}0.0183^{* *} \\
(0.00934)\end{array}$ & $\begin{array}{c}0.0214^{* *} \\
(0.00933)\end{array}$ & $\begin{array}{c}0.0183^{*} \\
(0.00934) \\
\end{array}$ \\
\hline $\begin{array}{l}\text { firm-year fix. eff. } \\
\text { bank fix. eff. }\end{array}$ & & $\begin{array}{l}\text { yes } \\
\text { yes }\end{array}$ & yes & $\begin{array}{l}\text { yes } \\
\text { yes }\end{array}$ & yes & $\begin{array}{l}\text { yes } \\
\text { yes }\end{array}$ & yes & $\begin{array}{l}\text { yes } \\
\text { yes }\end{array}$ & yes \\
\hline bank-year fix. eff. & & & yes & & yes & & yes & & yes \\
\hline Obs. & & 118643 & 118643 & 118643 & 118643 & 117494 & 117494 & 117494 & 117494 \\
\hline
\end{tabular}

Notes: Robust standard errors are in parentheses. ${ }^{*},{ }^{* *}$, and ${ }^{* * *}$ denote significance levels at $0.10,0.05$, and 0.01 , respectively. The dependent variable is $\triangle$ LOAN, which indicates a growth rate of a total amount of loans outstanding. BCAP denotes a regulatory capital ratio of a lending bank on the columns (1) to (4), while it denotes a market capital ratio on the columns (5) to (8). FQ and

FDD denote a Tobin's $q$ and a measure of distance to default of a borrowing firm, respectively. The results on the columns (1), (3), 
Table 3: Further results on estimating bank loan equations (A) Nonlinear specification

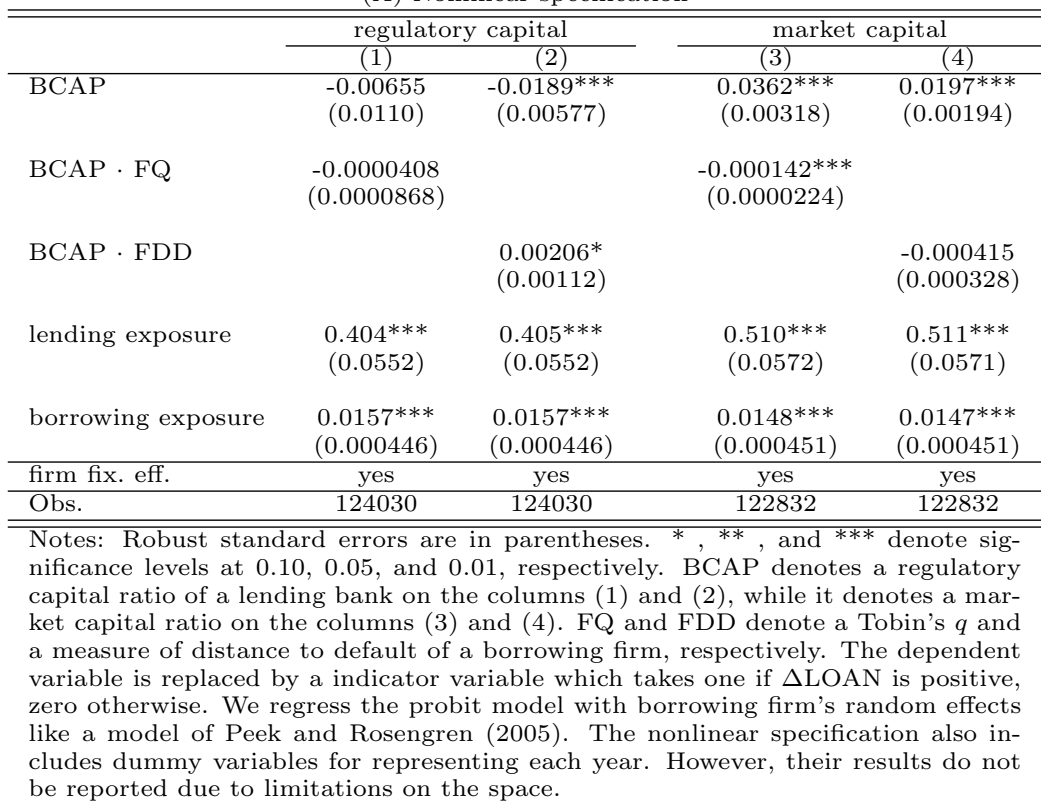

(B) Use of a lending exposure to real estate as a bank capital variable

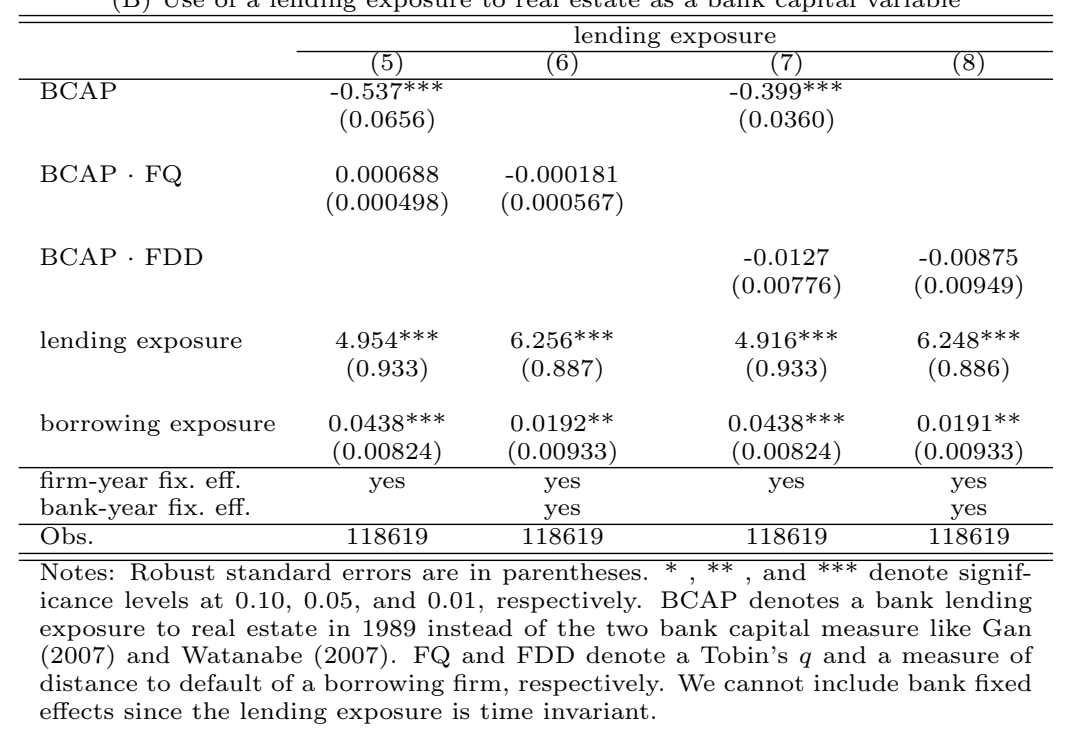


Table 4: Results on estimating bank loan equations with subsamples classified by the market capital ratio

\begin{tabular}{|c|c|c|c|c|c|c|c|c|c|c|c|c|}
\hline & \multicolumn{4}{|c|}{ low market capital } & \multicolumn{4}{|c|}{ middle market capital } & \multicolumn{4}{|c|}{ high market capital } \\
\hline & (1) & $(2)$ & (3) & (4) & (5) & $(6)$ & $(7)$ & $(8)$ & (9) & $(10)$ & $(11)$ & (12) \\
\hline BCAP & $\begin{array}{c}2.522^{* * *} \\
(0.571)\end{array}$ & & $\begin{array}{c}1.693^{* * *} \\
(0.352)\end{array}$ & & $\begin{array}{c}1.748^{* * *} \\
(0.608)\end{array}$ & & $\begin{array}{c}0.933^{* * *} \\
(0.358)\end{array}$ & & $\begin{array}{c}1.136^{* * *} * \\
(0.310)\end{array}$ & & $\begin{array}{c}0.821^{* * *} \\
(0.188)\end{array}$ & \\
\hline $\mathrm{BCAP} \cdot \mathrm{FQ}$ & $\begin{array}{l}-0.00366 \\
(0.00382)\end{array}$ & $\begin{array}{l}0.000362 \\
(0.00386)\end{array}$ & & & $\begin{array}{c}-0.00756^{*} \\
(0.00429)\end{array}$ & $\begin{array}{l}-0.00646 \\
(0.00434)\end{array}$ & & & $\begin{array}{l}-0.00257 \\
(0.00216)\end{array}$ & $\begin{array}{l}-0.00225 \\
(0.00224)\end{array}$ & & \\
\hline BCAP $\cdot$ FDD & & & $\begin{array}{l}0.0889 * \\
(0.0510)\end{array}$ & $\begin{array}{c}0.0645 \\
(0.0510)\end{array}$ & & & $\begin{array}{l}-0.0363 \\
(0.0595)\end{array}$ & $\begin{array}{l}-0.0500 \\
(0.0580)\end{array}$ & & & $\begin{array}{c}-0.00284 \\
(0.0315)\end{array}$ & $\begin{array}{l}-0.0117 \\
(0.0318)\end{array}$ \\
\hline lending exposure & $\begin{array}{c}9.416^{* * *} \\
(1.546)\end{array}$ & $\begin{array}{c}9.628^{* * * *} \\
(1.549)\end{array}$ & $\begin{array}{c}9.418^{* * *} \\
(1.549)\end{array}$ & $\begin{array}{c}9.628^{* * *} \\
(1.551)\end{array}$ & $\begin{array}{c}0.222 \\
(1.901)\end{array}$ & $\begin{array}{c}0.269 \\
(1.906)\end{array}$ & $\begin{array}{c}0.196 \\
(1.900)\end{array}$ & $\begin{array}{c}0.247 \\
(1.906)\end{array}$ & $\begin{array}{l}5.794 * * \\
(2.488)\end{array}$ & $\begin{array}{l}5.716^{* *} \\
(2.495)\end{array}$ & $\begin{array}{l}5.781^{* *} \\
(2.489)\end{array}$ & $\begin{array}{l}5.714^{* *} \\
(2.496)\end{array}$ \\
\hline borrowing exposure & $\begin{array}{c}0.194^{* * *} \\
(0.0260)\end{array}$ & $\begin{array}{c}0.183^{* * *} \\
(0.0261)\end{array}$ & $\begin{array}{c}0.194^{* * *} \\
(0.0260)\end{array}$ & $\begin{array}{c}0.183^{* * *} \\
(0.0261)\end{array}$ & $\begin{array}{c}0.0590^{* * *} \\
(0.0201)\end{array}$ & $\begin{array}{c}0.0588^{* * *} \\
(0.0201)\end{array}$ & $\begin{array}{c}0.0590 * * * \\
(0.0201)\end{array}$ & $\begin{array}{c}0.0589^{* * *} \\
(0.0201)\end{array}$ & $\begin{array}{c}-0.0740^{* * *} \\
(0.0168)\end{array}$ & $\begin{array}{c}-0.0743^{* * *} \\
(0.0168)\end{array}$ & $\begin{array}{c}-0.0739^{* * *} \\
(0.0168)\end{array}$ & $\begin{array}{c}-0.0742^{* * *} \\
(0.0168)\end{array}$ \\
\hline firm-year fix. eff. & yes & yes & yes & yes & yes & yes & yes & yes & yes & yes & yes & yes \\
\hline $\begin{array}{l}\text { bank fix. eff. } \\
\text { bank-year fix. eff. }\end{array}$ & yes & & yes & & yes & & yes & & yes & & yes & \\
\hline $\begin{array}{l}\text { regulatory capital } \\
\text { mean }\end{array}$ & & & & & & & & & & & & \\
\hline $\begin{array}{l}\text { std. dev. } \\
\text { market capital }\end{array}$ & & & & & & & & & & & & \\
\hline mean & & & & & & & & & & & 03 & \\
\hline std. dev. & & $\frac{1.2}{30800}$ & & & & & & & & & & \\
\hline
\end{tabular}

Notes: Robust standard errors are in parentheses. ${ }^{*},{ }^{* *}$, and ${ }^{* * *}$ denote significance levels at $0.10,0.05$, and 0.01 , respectively. BCAP denotes a market capital ratio on the all (first tertile), the middle 34th percentile (second tertile), and the bottom 33th percentile (third tertile) of banks as high, middle, and low market capital banks. 
Table 5: Results on estimating bank loan equations with subsamples classified by the regulatory capital ratio

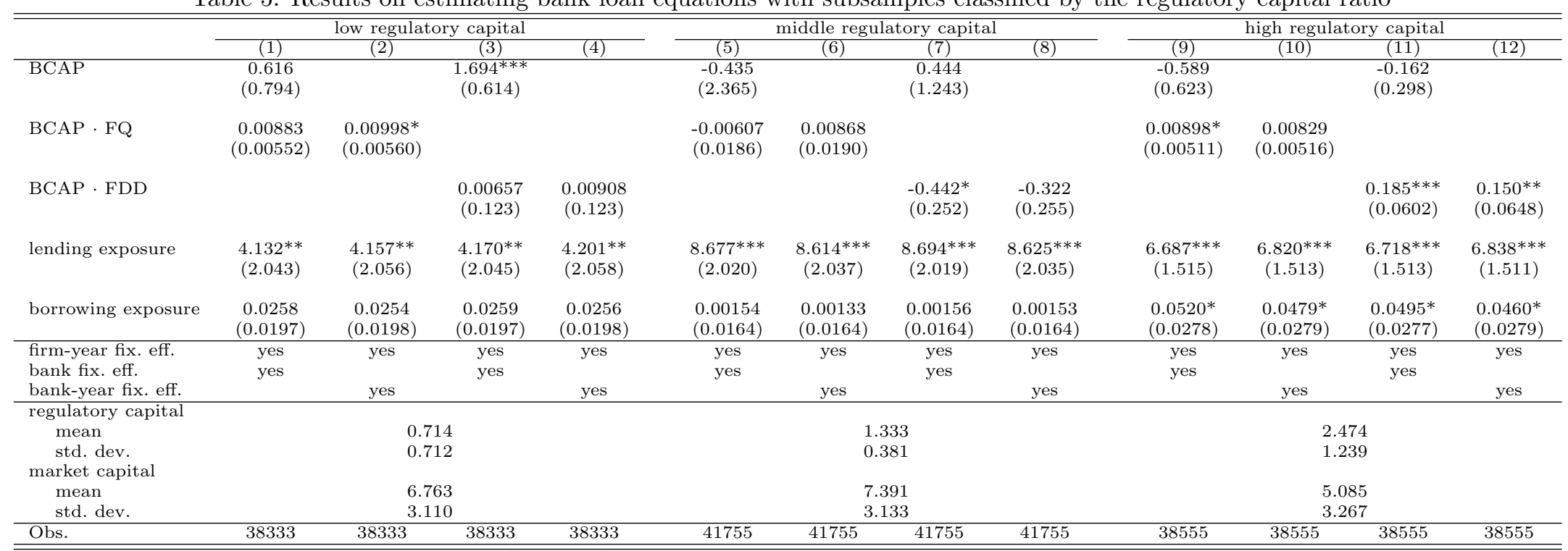

Notes: Robust standard errors are in parentheses. ${ }^{*},{ }^{* *}$, and ${ }^{* * *}$ denote significance levels at $0.10,0.05$, and 0.01, respectively. BCAP denotes a regulatory capital ratio

on the all columns. FQ and FDD denote a Tobin's $q$ and a measure of distance to default of a borrowing firm, respectively. To construct the three subsamples, we set the top 33th percentile (first tertile), the middle 34th percentile (second tertile) and the bottom 33th percentile (third tertile) of banks as high, middle and low regulatory capital banks. 
Table 6: Results on estimating bank loan equations with the simultaneous control (FQ)

\begin{tabular}{|c|c|c|c|c|}
\hline & $(1)$ & (2) & (3) & (4) \\
\hline REGCAP & $\begin{array}{l}-0.541^{*} \\
(0.283)\end{array}$ & & $\begin{array}{l}-0.404 \\
(0.491)\end{array}$ & \\
\hline REGCAP $\cdot$ FQ & $\begin{array}{c}0.00673^{* * *} \\
(0.00224)\end{array}$ & $\begin{array}{c}0.00502 * * \\
(0.00229)\end{array}$ & $\begin{array}{c}0.00812^{* *} \\
(0.00390)\end{array}$ & $\begin{array}{c}0.00155 \\
(0.00402)\end{array}$ \\
\hline MARCAP & $\begin{array}{c}0.384^{* * *} \\
(0.111)\end{array}$ & & $\begin{array}{c}0.425^{* *} \\
(0.175)\end{array}$ & \\
\hline MARCAP $\cdot$ FQ & $\begin{array}{c}-0.00128^{* *} \\
(0.000643)\end{array}$ & $\begin{array}{c}0.000531 \\
(0.000650)\end{array}$ & $\begin{array}{c}-0.000970 \\
(0.00120)\end{array}$ & $\begin{array}{r}-0.000529 \\
(0.00123)\end{array}$ \\
\hline REGCAP $\cdot$ MARCAP & & & $\begin{array}{l}-0.0486 \\
(0.0881)\end{array}$ & \\
\hline REGCAP $\cdot$ MARCAP $\cdot$ FQ & & & $\begin{array}{c}-0.000219 \\
(0.000666)\end{array}$ & $\begin{array}{c}0.000697 \\
(0.000699)\end{array}$ \\
\hline lending exposure & $\begin{array}{c}6.790^{* * * *} \\
(0.893)\end{array}$ & $\begin{array}{c}6.895^{* * *} \\
(0.902)\end{array}$ & $\begin{array}{c}6.773^{* * *} \\
(0.893)\end{array}$ & $\begin{array}{c}6.899 * * * \\
(0.902)\end{array}$ \\
\hline borrowing exposure & $\begin{array}{l}0.0217^{* *} \\
(0.00933)\end{array}$ & $\begin{array}{l}0.0183^{* *} \\
(0.00934)\end{array}$ & $\begin{array}{l}0.0218^{* *} \\
(0.00934)\end{array}$ & $\begin{array}{l}0.0184^{* *} \\
(0.00934)\end{array}$ \\
\hline $\begin{array}{l}\text { firm-year fix. eff. } \\
\text { bank fix. eff. } \\
\text { bank-year fix. eff. }\end{array}$ & $\begin{array}{l}\text { yes } \\
\text { yes }\end{array}$ & $\begin{array}{l}\text { yes } \\
\text { yes }\end{array}$ & $\begin{array}{l}\text { yes } \\
\text { yes }\end{array}$ & $\begin{array}{l}\text { yes } \\
\text { yes }\end{array}$ \\
\hline Obs. & 117494 & 117494 & 117494 & 117494 \\
\hline
\end{tabular}


Table 7: Results on estimating bank loan equations with the simultaneous control (FDD)

\begin{tabular}{|c|c|c|c|c|}
\hline & (1) & (2) & (3) & (4) \\
\hline REGCAP & $\begin{array}{l}0.0745 \\
(0.144)\end{array}$ & & $\begin{array}{c}0.317 \\
(0.258)\end{array}$ & \\
\hline REGCAP $\cdot$ FDD & $\begin{array}{l}0.0474^{*} \\
(0.0286)\end{array}$ & $\begin{array}{l}-0.0109 \\
(0.0304)\end{array}$ & $\begin{array}{c}0.0589 \\
(0.0531)\end{array}$ & $\begin{array}{l}-0.0505 \\
(0.0656)\end{array}$ \\
\hline MARCAP & $\begin{array}{c}0.260^{* * * *} \\
(0.0783)\end{array}$ & & $\begin{array}{c}0.327^{* * *} \\
(0.0980)\end{array}$ & \\
\hline MARCAP $\cdot$ FDD & $\begin{array}{c}-0.0149^{*} \\
(0.00867)\end{array}$ & $\begin{array}{c}-0.0124 \\
(0.00913)\end{array}$ & $\begin{array}{l}-0.0129 \\
(0.0137)\end{array}$ & $\begin{array}{c}-0.0255^{*} \\
(0.0148)\end{array}$ \\
\hline REGCAP $\cdot$ MARCAP & & & $\begin{array}{l}-0.0643 \\
(0.0427)\end{array}$ & \\
\hline REGCAP $\cdot$ MARCAP $\cdot$ FDD & & & $\begin{array}{c}-0.00178 \\
(0.00656)\end{array}$ & $\begin{array}{c}0.00739 \\
(0.00833)\end{array}$ \\
\hline lending exposure & $\begin{array}{c}6.773^{* * * *} \\
(0.892)\end{array}$ & $\begin{array}{c}6.919^{* * *} \\
(0.902)\end{array}$ & $\begin{array}{c}6.757^{* * *} \\
(0.892)\end{array}$ & $\begin{array}{c}6.926 * * * \\
(0.902)\end{array}$ \\
\hline borrowing exposure & $\begin{array}{c}0.0216^{* *} \\
(0.00933)\end{array}$ & $\begin{array}{c}0.0183^{*} \\
(0.00934)\end{array}$ & $\begin{array}{c}0.0218^{* *} \\
(0.00933)\end{array}$ & $\begin{array}{c}0.0182^{*} \\
(0.00934)\end{array}$ \\
\hline Obs. & 117494 & 117494 & 117494 & 117494 \\
\hline \multicolumn{5}{|c|}{$\begin{array}{l}\text { Notes: Robust standard errors are in parentheses. }{ }^{*}, * *, \text { and }{ }^{* * *} \text { denote sig- } \\
\text { nificance levels at } 0.10,0.05 \text {, and } 0.01 \text {, respectively. REGCAP and MARCAP } \\
\text { denote a regulatory capital ratio and a market capital ratio of a lending bank, } \\
\text { respectively. FDD denotes a measure of distance to default of a borrowing } \\
\text { firm. }\end{array}$} \\
\hline
\end{tabular}


Table 8: Results on subsample regressions with the simultaneous control (FQ)

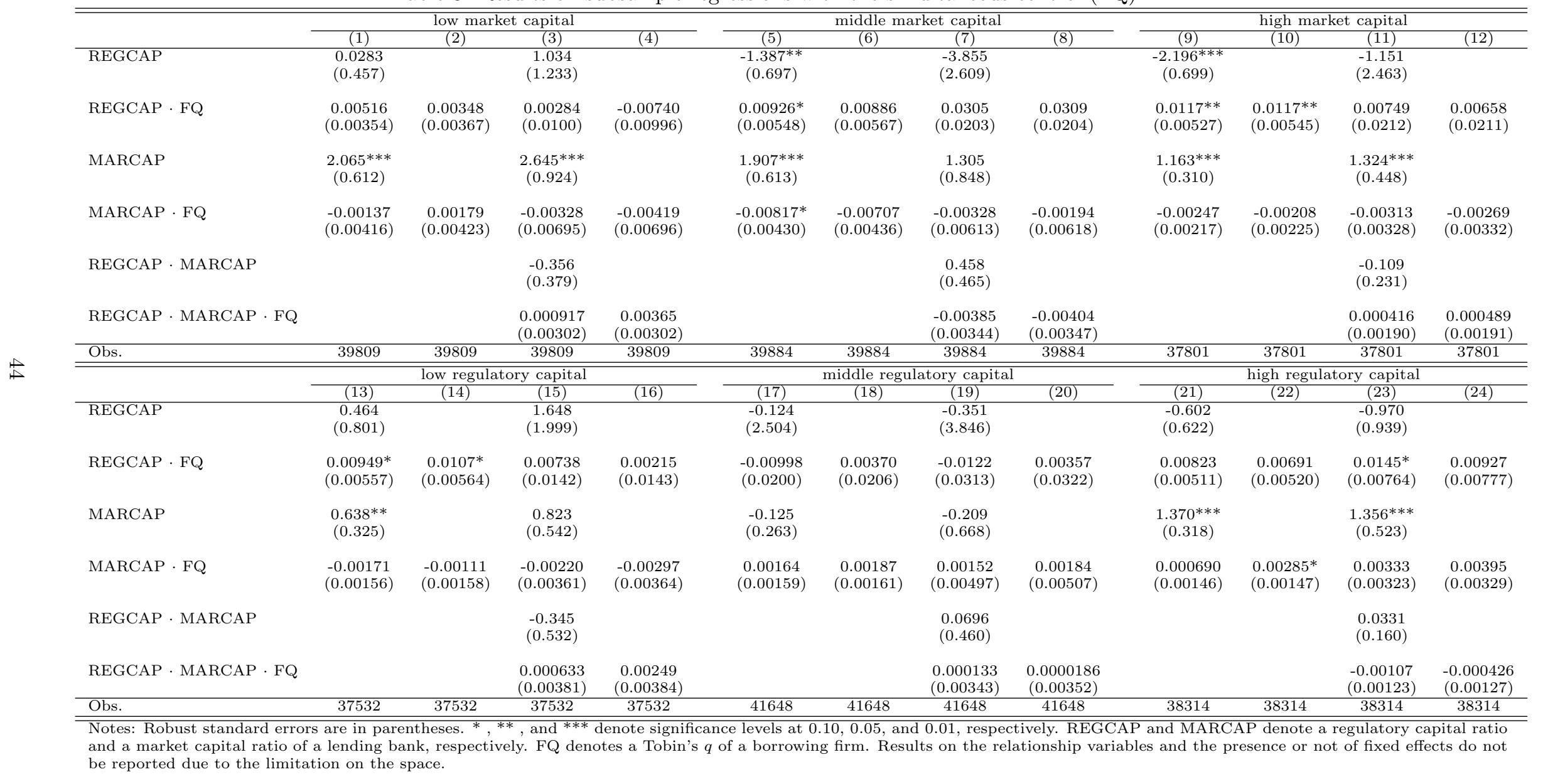


Table 9: Results on subsample regressions with the simultaneous control (FDD)

\begin{tabular}{|c|c|c|c|c|c|c|c|c|c|c|c|c|}
\hline & \multirow{2}{*}{\multicolumn{4}{|c|}{ low market capital }} & \multicolumn{4}{|c|}{ middle market capital } & \multicolumn{4}{|c|}{ "high market capital } \\
\hline & & & & (4) & $(5)$ & $(6)$ & $(7)$ & $(8)$ & $(9)$ & $(10)$ & $(11)$ & $(12)$ \\
\hline REGCAP & $\begin{array}{l}0.541^{* *} \\
(0.274)\end{array}$ & & $\begin{array}{l}1.351^{*} \\
(0.695)\end{array}$ & & $\begin{array}{l}-0.196 \\
(0.342)\end{array}$ & & $\begin{array}{c}0.284 \\
(1.376)\end{array}$ & & $\begin{array}{c}-1.248^{* * *} \\
(0.395)\end{array}$ & & $\begin{array}{l}-1.677 \\
(1.152)\end{array}$ & \\
\hline REGCAP $\cdot$ FDD & $\begin{array}{c}0.0267 \\
(0.0591)\end{array}$ & $\begin{array}{l}-0.0542 \\
(0.0623)\end{array}$ & $\begin{array}{c}-0.0324 \\
(0.157)\end{array}$ & $\begin{array}{l}-0.188 \\
(0.166)\end{array}$ & $\begin{array}{c}-0.0374 \\
(0.0548)\end{array}$ & $\begin{array}{l}-0.0545 \\
(0.0543)\end{array}$ & $\begin{array}{l}-0.234 \\
(0.269)\end{array}$ & $\begin{array}{l}-0.291 \\
(0.276)\end{array}$ & $\begin{array}{l}0.121^{* *} \\
(0.0471)\end{array}$ & $\begin{array}{c}0.0887^{*} \\
(0.0469)\end{array}$ & $\begin{array}{l}0.371^{*} \\
(0.225)\end{array}$ & $\begin{array}{c}0.213 \\
(0.235)\end{array}$ \\
\hline MARCAP & $\begin{array}{c}1.482^{* * *} * \\
(0.359)\end{array}$ & & $\begin{array}{c}1.933^{* * *} \\
(0.504)\end{array}$ & & $\begin{array}{c}0.988^{* * *} * \\
(0.352)\end{array}$ & & $\begin{array}{c}1.070^{* *} \\
(0.419)\end{array}$ & & $\begin{array}{c}0.854^{* * *} \\
(0.191)\end{array}$ & & $\begin{array}{c}0.793^{* * *} \\
(0.259)\end{array}$ & \\
\hline MARCAP $\cdot$ FDD & $\begin{array}{l}0.0984^{*} \\
(0.0522)\end{array}$ & $\begin{array}{c}0.0464 \\
(0.0523)\end{array}$ & $\begin{array}{c}0.0544 \\
(0.0946)\end{array}$ & $\begin{array}{l}-0.0258 \\
(0.0979)\end{array}$ & $\begin{array}{l}-0.0342 \\
(0.0560)\end{array}$ & $\begin{array}{l}-0.0456 \\
(0.0539)\end{array}$ & $\begin{array}{c}-0.0677 \\
(0.0664)\end{array}$ & $\begin{array}{l}-0.0872 \\
(0.0667)\end{array}$ & $\begin{array}{c}-0.00743 \\
(0.0325)\end{array}$ & $\begin{array}{l}-0.0174 \\
(0.0326)\end{array}$ & $\begin{array}{c}0.0234 \\
(0.0442)\end{array}$ & $\begin{array}{r}-0.00119 \\
(0.0450)\end{array}$ \\
\hline REGCAP $\cdot$ MARCAP & & & $\begin{array}{l}-0.279 \\
(0.224)\end{array}$ & & & & $\begin{array}{c}-0.0921 \\
(0.252)\end{array}$ & & & & $\begin{array}{l}0.0366 \\
(0.109)\end{array}$ & \\
\hline REGCAP · MARCAP · FDD & & & $\begin{array}{c}0.0212 \\
(0.0514)\end{array}$ & $\begin{array}{c}0.0458 \\
(0.0543)\end{array}$ & & & $\begin{array}{c}0.0365 \\
(0.0475)\end{array}$ & $\begin{array}{c}0.0442 \\
(0.0491)\end{array}$ & & & $\begin{array}{c}-0.0232 \\
(0.0193) \\
\end{array}$ & $\begin{array}{l}-0.0115 \\
(0.0200) \\
\end{array}$ \\
\hline Obs. & 39809 & 39809 & 39809 & 39809 & 39884 & 39884 & 39884 & 39884 & 37801 & 37801 & 37801 & 37801 \\
\hline & \multicolumn{4}{|c|}{ low regulatory capital } & \multicolumn{4}{|c|}{ middle regulatory capital } & \multicolumn{4}{|c|}{ high regulatory capital } \\
\hline REGCAP & $\begin{array}{c}(13) \\
1.559^{* *} \\
(0.619)\end{array}$ & $(14)$ & $\begin{array}{c}(15) \\
0.901 \\
(1.321)\end{array}$ & $(16)$ & $\begin{array}{c}(17) \\
0.293 \\
(1.262)\end{array}$ & $(18)$ & $\begin{array}{c}(19) \\
1.494 \\
(1.910)\end{array}$ & $(20)$ & $\begin{array}{c}(21) \\
-0.293 \\
(0.296)\end{array}$ & $(22)$ & $\begin{array}{c}(23) \\
-0.120 \\
(0.456)\end{array}$ & $(24)$ \\
\hline REGCAP $\cdot$ FDD & $\begin{array}{c}0.0231 \\
(0.124)\end{array}$ & $\begin{array}{l}0.0196 \\
(0.124)\end{array}$ & $\begin{array}{c}0.401 \\
(0.255)\end{array}$ & $\begin{array}{c}0.338 \\
(0.252)\end{array}$ & $\begin{array}{l}-0.419 \\
(0.259)\end{array}$ & $\begin{array}{l}-0.292 \\
(0.263)\end{array}$ & $\begin{array}{c}-0.882^{* *} \\
(0.419)\end{array}$ & $\begin{array}{c}-0.772^{*} \\
(0.428)\end{array}$ & $\begin{array}{c}0.196 * * * \\
(0.0589)\end{array}$ & $\begin{array}{c}0.151^{* *} \\
(0.0630)\end{array}$ & $\begin{array}{c}0.250^{* * *} \\
(0.0888)\end{array}$ & $\begin{array}{c}0.189^{*} \\
(0.0965)\end{array}$ \\
\hline MARCAP & $\begin{array}{c}0.609^{* *} \\
(0.266)\end{array}$ & & $\begin{array}{c}0.377 \\
(0.359)\end{array}$ & & $\begin{array}{c}0.129 \\
(0.171)\end{array}$ & & $\begin{array}{c}0.390 \\
(0.351)\end{array}$ & & $\begin{array}{c}1.494^{* * *} \\
(0.267)\end{array}$ & & $\begin{array}{c}1.681^{* * *} \\
(0.386)\end{array}$ & \\
\hline MARCAP $\cdot$ FDD & $\begin{array}{c}-0.0448^{* *} \\
(0.0215)\end{array}$ & $\begin{array}{c}-0.0427^{* *} \\
(0.0215)\end{array}$ & $\begin{array}{c}0.0369 \\
(0.0542)\end{array}$ & $\begin{array}{c}0.0268 \\
(0.0534)\end{array}$ & $\begin{array}{r}-0.00857 \\
(0.0182)\end{array}$ & $\begin{array}{l}-0.0121 \\
(0.0184)\end{array}$ & $\begin{array}{c}-0.0979 \\
(0.0607)\end{array}$ & $\begin{array}{l}-0.109^{*} \\
(0.0620)\end{array}$ & $\begin{array}{c}-0.00434 \\
(0.0167)\end{array}$ & $\begin{array}{c}-0.00505 \\
(0.0179)\end{array}$ & $\begin{array}{c}0.0267 \\
(0.0421)\end{array}$ & $\begin{array}{c}0.0181 \\
(0.0427)\end{array}$ \\
\hline REGCAP $\cdot$ MARCAP & & & $\begin{array}{c}0.197 \\
(0.338)\end{array}$ & & & & $\begin{array}{l}-0.217 \\
(0.250)\end{array}$ & & & & $\begin{array}{l}-0.0559 \\
(0.0836)\end{array}$ & \\
\hline REGCAP $\cdot$ MARCAP $\cdot$ FDD & & & $\begin{array}{l}-0.111^{*} \\
(0.0653)\end{array}$ & $\begin{array}{l}-0.0932 \\
(0.0648)\end{array}$ & & & $\begin{array}{c}0.0752 \\
(0.0491)\end{array}$ & $\begin{array}{c}0.0802 \\
(0.0503)\end{array}$ & & & $\begin{array}{l}-0.0107 \\
(0.0126)\end{array}$ & $\begin{array}{c}-0.00761 \\
(0.0131)\end{array}$ \\
\hline Obs. & 37532 & 37532 & 37532 & 37532 & 41648 & 41648 & 41648 & 41648 & 38314 & 38314 & 38314 & 38314 \\
\hline
\end{tabular}


Table 10: Summary statistics for bank capital equations

\begin{tabular}{lccccc}
\hline \hline \multicolumn{1}{c}{ Variable } & Obs. & Mean & Std. Dev. & Min. & Max. \\
\hline market capital ratio & 710 & 5.359 & 2.273 & .602 & 15.723 \\
regulatory capital ratio & 824 & 1.388 & 1.391 & -5.01 & 9.48 \\
bank charter value $\left(\mathrm{BQ}_{i t-1}\right)$ & 704 & 102.24 & 2.136 & 98.272 & 114.997 \\
profitability $\left(\mathrm{PROF}_{i t-1}\right)$ & 824 & .066 & .298 & -2.61 & .598 \\
$\log \left(\right.$ total asset) $\left(\mathrm{SIZE}_{i t-1}\right)$ & 824 & 14.727 & 1.365 & 12.303 & 18.171 \\
$\operatorname{collateral}$ assets $\left(\mathrm{COL}_{i t-1}\right)$ & 824 & 23.409 & 5.943 & 11.596 & 44.308 \\
$\log \left(\right.$ asset volatility) $\left(\sigma_{i t-1}\right)$ & 704 & .225 & .697 & -4.531 & 2.62 \\
\hline
\end{tabular}

Notes: Estimation samples are from March 1993 to March 1998. Lagged variables, or all explanatory variables, are from March 1992 to March 1997. 
Table 11: Estimation results on determinants of the two bank capital ratio (A) market capital

\begin{tabular}{|c|c|c|c|c|c|}
\hline & (1) & $(2)$ & & $(3)$ & $(4)$ \\
\hline BQ & $\begin{array}{c}0.259^{* * *} \\
(0.0431)\end{array}$ & $\begin{array}{c}0.226^{* * *} \\
(0.0523)\end{array}$ & $\mathrm{BQ}$ & $\begin{array}{c}0.0695 \\
(0.0447)\end{array}$ & $\begin{array}{c}0.0703 \\
(0.0427)\end{array}$ \\
\hline PROF & $\begin{array}{c}0.315^{* *} \\
(0.145)\end{array}$ & $\begin{array}{c}1.200 * * * \\
(0.300)\end{array}$ & PROF & $\begin{array}{c}0.325 \\
(0.242)\end{array}$ & $\begin{array}{l}0.0635 \\
(0.160)\end{array}$ \\
\hline SIZE & $\begin{array}{c}1.997 * * \\
(0.959)\end{array}$ & $\begin{array}{c}1.931^{* *} \\
(0.957)\end{array}$ & SIZE & $\begin{array}{c}1.003 \\
(1.204)\end{array}$ & $\begin{array}{c}1.105 \\
(1.065)\end{array}$ \\
\hline $\mathrm{COL}$ & $\begin{array}{c}0.0813^{* * *} \\
(0.0245)\end{array}$ & $\begin{array}{c}0.0799 * * * \\
(0.0262)\end{array}$ & $\mathrm{COL}$ & $\begin{array}{c}0.0151 \\
(0.0231)\end{array}$ & $\begin{array}{c}0.0127 \\
(0.0235)\end{array}$ \\
\hline$\sigma$ & $\begin{array}{l}0.204^{* *} \\
(0.0959)\end{array}$ & $\begin{array}{c}0.419 * * \\
(0.161)\end{array}$ & $\sigma$ & $\begin{array}{c}0.0675 \\
(0.0847)\end{array}$ & $\begin{array}{c}0.0809 \\
(0.0863)\end{array}$ \\
\hline $\mathrm{D}_{\text {low }}^{M} \cdot \mathrm{BQ}$ & & $\begin{array}{c}0.0811 \\
(0.0944)\end{array}$ & $\mathrm{D}_{h i g h}^{R} \cdot \mathrm{BQ}$ & & $\begin{array}{l}-0.0840 \\
(0.0799)\end{array}$ \\
\hline $\mathrm{D}_{\text {low }}^{M} \cdot \mathrm{PROF}$ & & $\begin{array}{c}-1.145^{* * *} \\
(0.315)\end{array}$ & $\mathrm{D}_{h i g h}^{R} \cdot \mathrm{PROF}$ & & $\begin{array}{c}1.031^{* * *} \\
(0.357)\end{array}$ \\
\hline $\mathrm{D}_{\text {low }}^{M} \cdot \mathrm{SIZE}$ & & $\begin{array}{c}-0.0606 \\
(0.165)\end{array}$ & $\mathrm{D}_{h i g h}^{R} \cdot \mathrm{SIZE}$ & & $\begin{array}{c}-0.0526 \\
(0.164)\end{array}$ \\
\hline $\mathrm{D}_{\text {low }}^{M} \cdot \mathrm{COL}$ & & $\begin{array}{l}-0.0264 \\
(0.0218)\end{array}$ & $\mathrm{D}_{\text {high }}^{R} \cdot \mathrm{COL}$ & & $\begin{array}{l}0.00190 \\
(0.0237)\end{array}$ \\
\hline $\mathrm{D}_{\text {low }}^{M} \cdot \sigma$ & & $\begin{array}{c}-0.244^{*} \\
(0.141)\end{array}$ & $\mathrm{D}_{h i g h}^{R} \cdot \sigma$ & & $\begin{array}{l}0.0795 \\
(0.241)\end{array}$ \\
\hline $\mathrm{D}_{\text {low }}^{M}$ & & $\begin{array}{c}-6.604 \\
(9.783)\end{array}$ & $\mathrm{D}_{h i g h}^{R}$ & & $\begin{array}{c}9.212 \\
(8.682)\end{array}$ \\
\hline constant & $\begin{array}{c}-52.88^{* * *} \\
(15.94)\end{array}$ & $\begin{array}{c}-48.60^{* * *} \\
(17.28)\end{array}$ & constant & $\begin{array}{c}-21.54 \\
(19.36)\end{array}$ & $\begin{array}{l}-23.04 \\
(17.40)\end{array}$ \\
\hline Obs. & 701 & 701 & Obs. & 704 & 704 \\
\hline
\end{tabular}

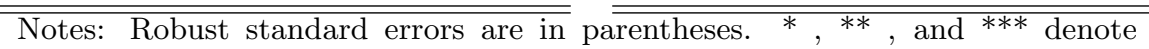
significance levels at $0.10,0.05$, and 0.01 , respectively. The dependent variable is the market capital ratio in the panel (A), while it is the regulatory capital ratio in the panel (B). $\mathrm{D}_{\text {low }}^{M}$ denotes a dummy variable which takes one if a bank is classified into a low market capital ratio, zero otherwise. $\mathrm{D}_{\text {high }}^{M}$ denotes a dummy variable which takes one if a bank is classified into a high regulatory capital ratio, zero otherwise. Estimating equations also include dummy variables for representing each year. However, their results do not be reported due to limitations on the space. 
Table 12: Results on estimating bank loan equations including the determinantes of the market capital

\begin{tabular}{|c|c|c|c|c|c|c|}
\hline MARCAP & $\begin{array}{c}(1) \\
0.234^{* * *} \\
(0.0675)\end{array}$ & $\begin{array}{c}(2) \\
1.388^{* * *} \\
(0.245)\end{array}$ & $\begin{array}{c}(3) \\
0.204^{* * *} \\
(0.0684)\end{array}$ & $\begin{array}{c}(4) \\
0.319^{* * *} \\
(0.0677)\end{array}$ & $\begin{array}{c}(5) \\
0.260^{* * *} \\
(0.0726)\end{array}$ & $\begin{array}{c}(6) \\
0.00480 \\
(0.0728)\end{array}$ \\
\hline BQ & & $\begin{array}{c}-1.058^{* * *} \\
(0.215)\end{array}$ & & & & \\
\hline PROF & & & $\begin{array}{c}0.563^{* *} \\
(0.246)\end{array}$ & & & \\
\hline SIZE & & & & $\begin{array}{c}12.72^{* * *} \\
(1.072)\end{array}$ & & \\
\hline $\mathrm{COL}$ & & & & & $\begin{array}{l}-0.0296 \\
(0.0326)\end{array}$ & \\
\hline$\sigma$ & & & & & & $\begin{array}{c}3.018^{* * *} \\
(0.364)\end{array}$ \\
\hline lending exposure & $\begin{array}{c}7.260^{* * *} \\
(0.879)\end{array}$ & $\begin{array}{c}7.292^{* * *} \\
(0.878)\end{array}$ & $\begin{array}{c}7.267^{* * * *} \\
(0.878)\end{array}$ & $\begin{array}{c}7.332^{* * *} \\
(0.881)\end{array}$ & $\begin{array}{c}7.263^{* * *} \\
(0.879)\end{array}$ & $\begin{array}{c}7.261^{* * *} \\
(0.878)\end{array}$ \\
\hline borrowing exposure & $\begin{array}{c}0.0000306 \\
(0.0000881) \\
\end{array}$ & $\begin{array}{c}0.0000250 \\
(0.0000898) \\
\end{array}$ & $\begin{array}{c}0.0000238 \\
(0.0000888) \\
\end{array}$ & $\begin{array}{c}0.0000996 \\
(0.0000940) \\
\end{array}$ & $\begin{array}{c}0.0000270 \\
(0.0000876) \\
\end{array}$ & $\begin{array}{c}0.0000338 \\
(0.0000889) \\
\end{array}$ \\
\hline $\begin{array}{l}\text { firm-year fix. eff. } \\
\text { bank fix. eff. }\end{array}$ & $\begin{array}{l}\text { yes } \\
\text { yes }\end{array}$ & $\begin{array}{l}\text { yes } \\
\text { yes }\end{array}$ & $\begin{array}{l}\text { yes } \\
\text { yes }\end{array}$ & $\begin{array}{l}\text { yes } \\
\text { yes }\end{array}$ & $\begin{array}{l}\text { yes } \\
\text { yes }\end{array}$ & $\begin{array}{l}\text { yes } \\
\text { yes }\end{array}$ \\
\hline Obs. & 119384 & 119384 & 119384 & 119384 & 119384 & 119384 \\
\hline
\end{tabular}




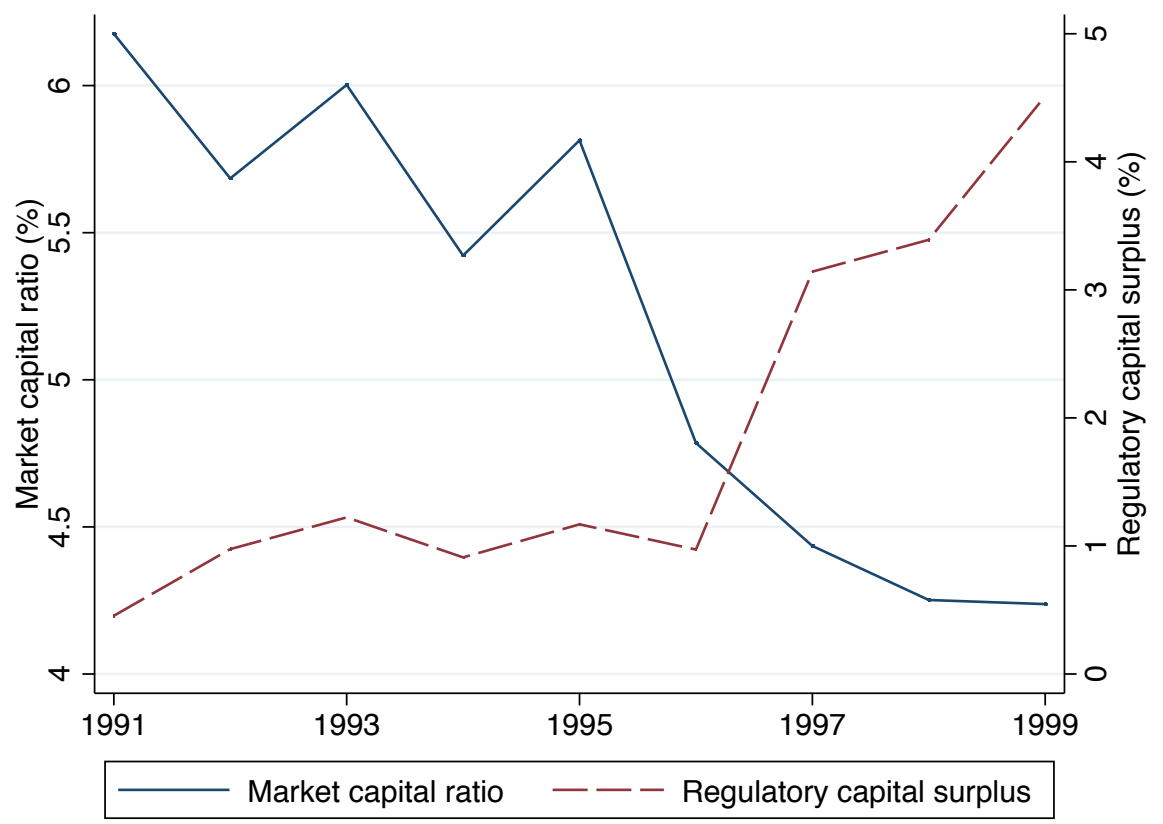

Figure 1: Means of bank market capital ratio and regulatory capital surplus

Notes: The solid line represents means of the bank market capital ratio at each year, and the dashed line represents means of the bank regulatory capital surplus at each year. 


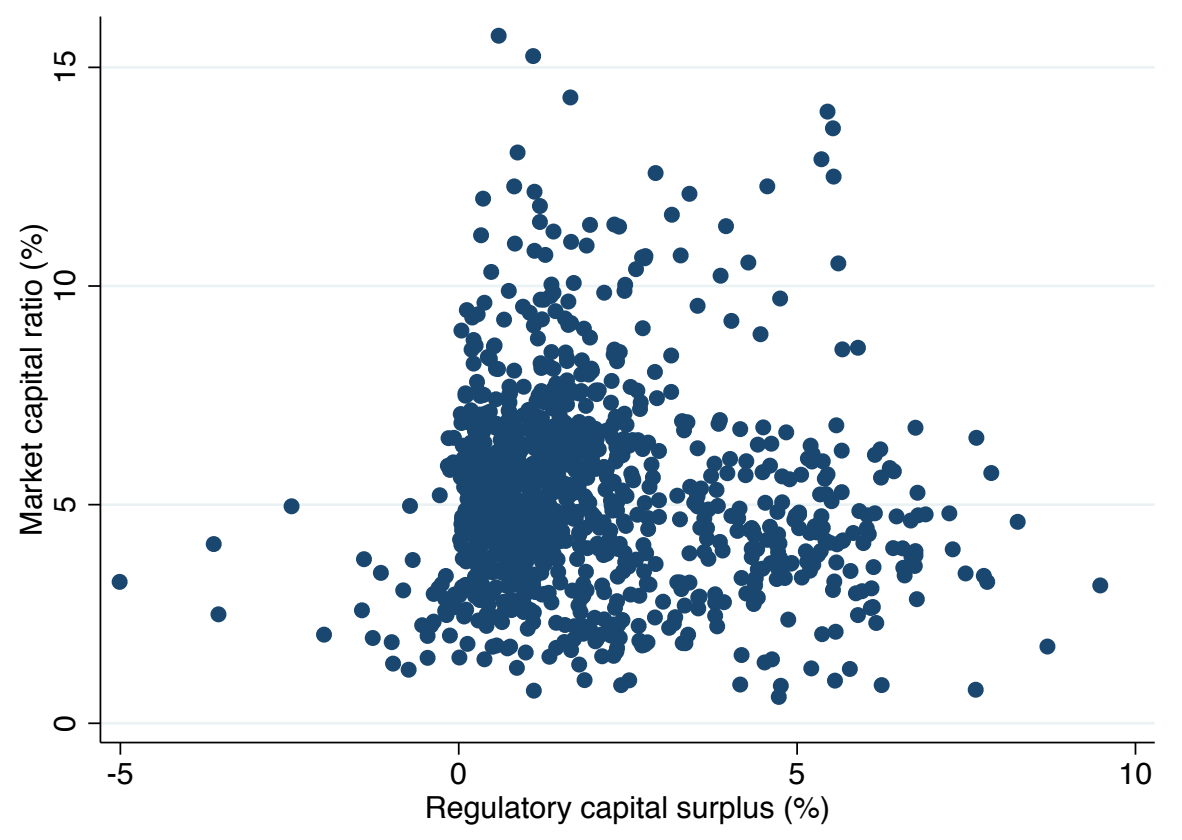

Figure 2: Scatter plot of between the two bank capital ratio 

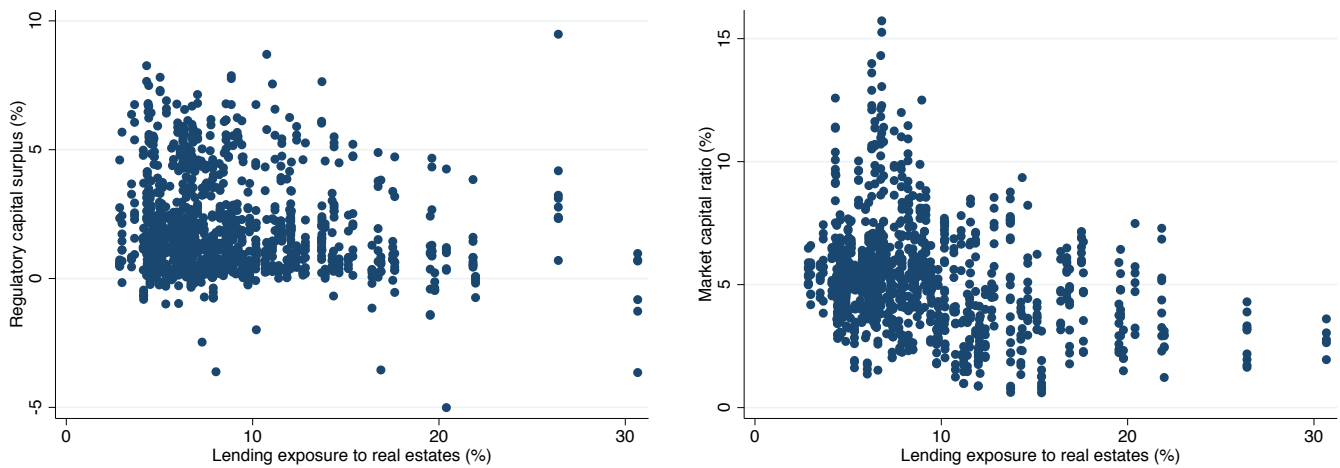

Figure 3: Scatter plot of between lending exposure of real estates and the bank capital ratio

Notes: The left panel is a scatter plot of between the lending exposure of real estates and the regulatory capital surplus, and the right panel is that of between the lending exposure of real estates and the market capital ratio. 
(A) Regulatory capital
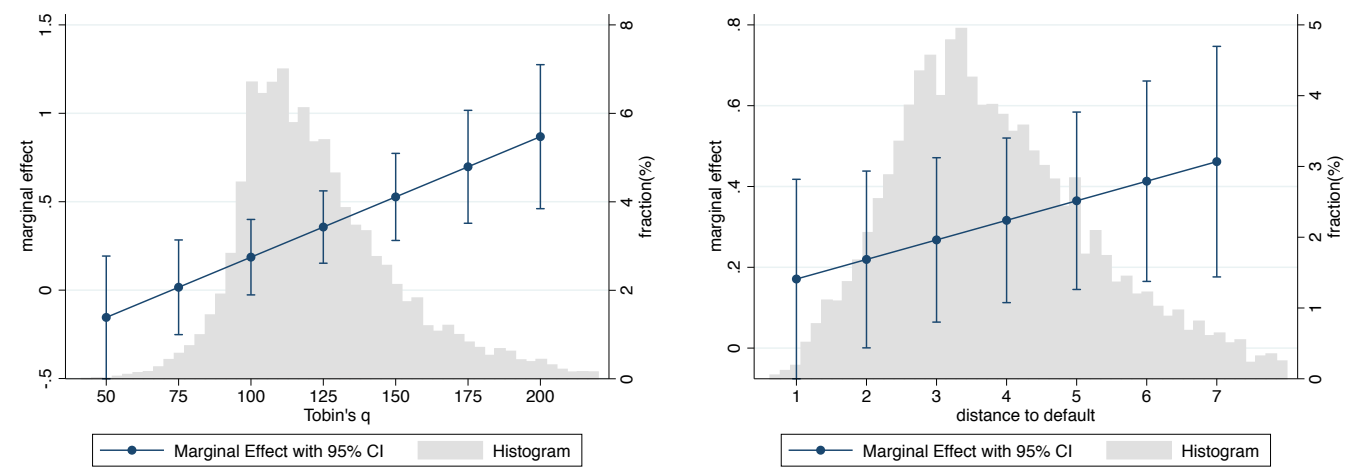

(B) Market capital
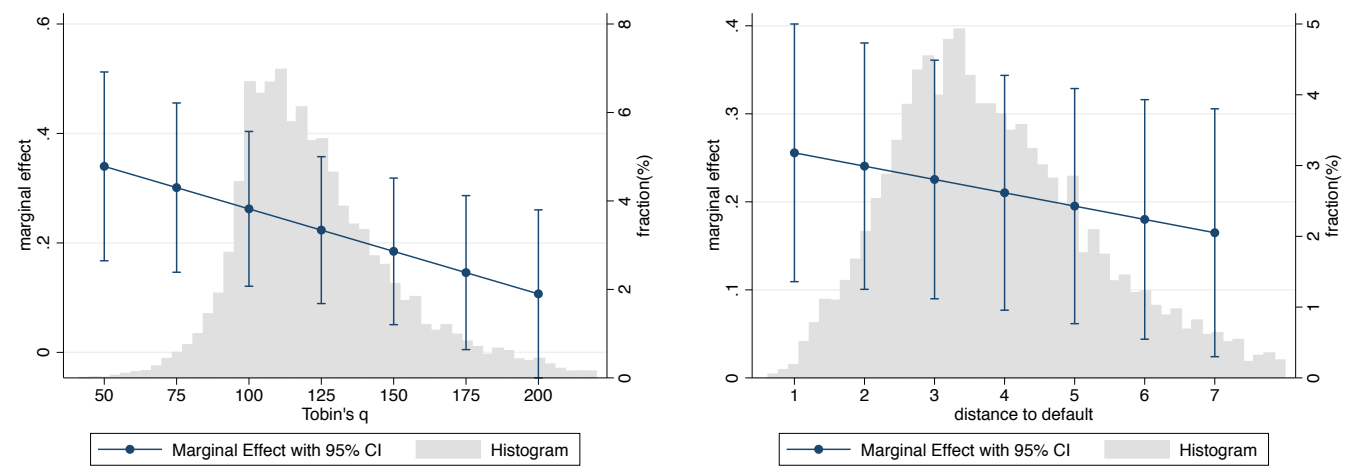

Figure 4: Average supply effects of bank capital on lending

Notes: Dots represent point estimates of average marginal effects of bank capital measure, BCAP, at a representative value of the firm performance variables in the bank loan equations reported on Table 2. Capped vertical lines represent their confidence intervals with 95 percent significance level calculated by the delta method. Shadow areas represent histograms of the firm performance variables correspond to the right axes. 


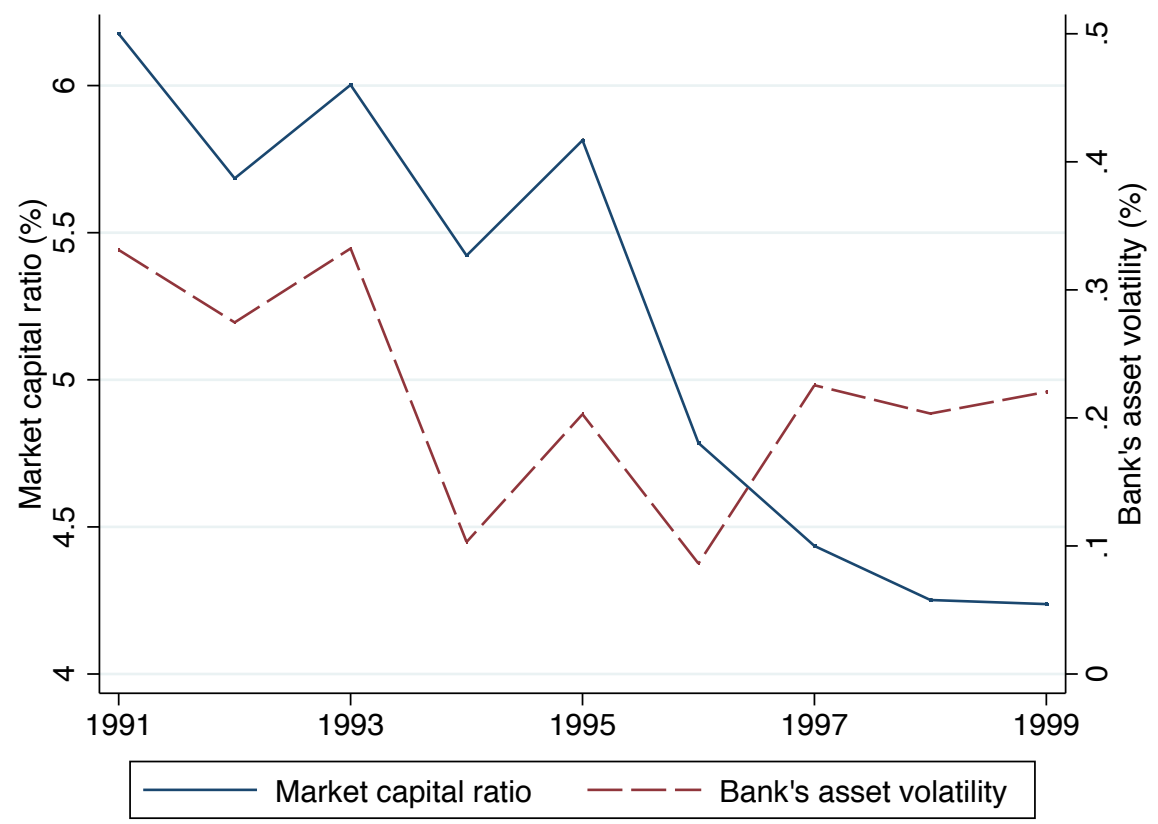

Figure 5: Means of bank market capital ratio and the asset volatility

Notes: The solid line represents means of the bank market capital ratio at each year, it is the same as Figure 1, and the dashed line represents means of the logarithmic value of the bank's asset volatility at each year. 